\title{
Subcutaneous administration of the retrograde transport inhibitor Retro-2.1 formulated in a PLGA-PEG-PLGA thermosensitive hydrogel leads to a sustained release of the drug and a better control of its metabolism in vivo
}

Robin Vinck, ${ }^{a, b}$ Laetitia Anvi Nguyen, ${ }^{c}$ Mathilde Munier, ${ }^{b}$ Lucie Caramelle, ${ }^{a}$ Diana Karpman, ${ }^{d}$ Julien Barbier, ${ }^{a}$ Jean-Christophe Cintrat $*{ }^{b}$ Alain Pruvost ${ }^{c}$ and Daniel Gillet ${ }^{*},{ }^{a}$

a Université Paris-Saclay, CEA, INRAE, Département Médicaments et Technologies pour la Santé (DMTS), SIMoS, 91191 Gif-sur-Yvette, France

b Université Paris-Saclay, CEA, INRAE, Département Médicaments et Technologies pour la Santé (DMTS), SCBM, 91191 Gif-sur-Yvette, France

c Université Paris-Saclay, CEA, INRAE, Département Médicaments et Technologies pour la Santé (DMTS), SPI, 91191 Gif-sur-Yvette, France

d Department of Pediatrics, Clinical Sciences Lund, Lund University, Lund, Sweden

* Corresponding authors: Daniel.gillet@cea.fr; Tel. +33 (0)1 $6908 \quad 76 \quad 46 . \quad$ Jeanchristophe.cintrat@ cea.fr; Tel. +33 (0)016908 2107

\section{Keywords:}

Retrograde transport inhibitor, broad-spectrum, Retro-2.1, formulation, thermosensitive hydrogel, pharmacokinetic, metabolism. 


\section{ABSTRACT}

A recently developed inhibitor of the retrograde transport, namely Retro-2.1, proved to be a potent and broad-spectrum lead in vitro against intracellular pathogens such as toxins, parasites, intracellular bacteria, and viruses. In order to circumvent its low aqueous solubility, a formulation in poly(ethylene glycol)-bloc-poly(D,L)lactide micelles was developed. This formulation allowed studying Retro-2.1 pharmacokinetic parameters in mice following intravenous or intraperitoneal injection, revealing a low blood circulation time. To explain these poor pharmacokinetic parameters, Retro-2.1 metabolic stability was studied in vitro and in vivo revealing a fast cytochrome P-450-mediated metabolism into a less potent hydroxylated analog. Subcutaneous injection of Retro- 2.1 formulated in a biocompatible and bioresorbable polymerbased thermosensitive hydrogel allowed for a sustained-release of the drug and a better control of its metabolism. This study gives a guideline on how to administer this promising lead in vivo in order to study its efficacy.

\section{INTRODUCTION}

The 2-(((5-methylthiophen-2-yl)methylene)amino)-N-phenylbenzamide, also called Retro-2 (Fig. 1), was first identified during a phenotypic high-throughput screening campaign as an inhibitor of ricin, a highly potent plant toxin. The study of its mode of action revealed that Retro- 2 is able to inhibit the retrograde transport of the ricin toxin to the endoplasmic reticulum, preventing its eventual translocation to the cytoplasm. Thanks to this unique mode of action, Retro- 2 has the potential to act as a broad-spectrum drug candidate towards any pathogen exploiting the retrograde transport to replicate or to reach its intracellular target. ${ }^{1}$

Figure 1. Structures of Retro-2 and its first generation derivative Retro-2.1.

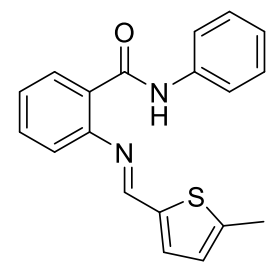

Retro

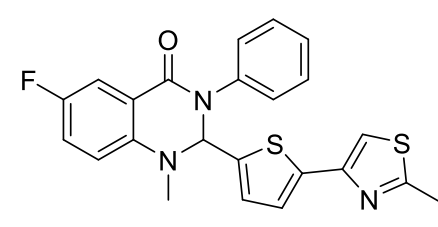

Retro- 
In order to further improve Retro-2 potency, a structure-activity relationship study was performed and led to the discovery of a more efficient version of the retrograde pathway inhibitor, the 6-fluoro-1-methyl-2-(5-(2-methylthiazol-4-yl)thiophen-2-yl)-3-phenyl-2,3dihydroquinazolin-4(1H)-one, namely Retro-2.1 (Fig. 1)). Of note, the (S)-enantiomer of Retro2.1 demonstrated the highest potency. ${ }^{2,3}$

Over the years, Retro- 2 and Retro-2.1 showed an ability to inhibit the effect or the proliferation of intracellular pathogens such as toxins, parasites, intracellular bacteria and viruses. ${ }^{1-16}$ This list of pathogens is consistently growing, with the recent addition of SARS-CoV-2, demonstrating the high therapeutical potential of the Retro- 2 series (Tab. 1). ${ }^{17}$ Moreover, the recent unravelling of its intracellular target unlocked the potential discovery of new applications. ${ }^{18}$ Of note, only a few of the tested pathogens were found to be unsensitive to the Retro-2 family (i.e. diphteria toxin, Clostridium botulinum neurotoxin A, dengue virus serotype 4, chikungunya virus and Venezuelan equine encephalitis virus). ${ }^{4}$

Tab. 1. Pathogens affected by Retro- 2 and its derivatives.

\begin{tabular}{|lll|}
\hline Class of pathogen & Pathogen & Reference \\
\hline Viruses & Ricin & 1,4 \\
\cline { 2 - 3 } & Shiga toxins & $1-3,5$ \\
\hline & Adeno Associated Virus & 6 \\
\cline { 2 - 3 } & Polyoma virus & 7,8 \\
\cline { 2 - 3 } & Papilloma virus & 8 \\
\cline { 2 - 3 } & Ebola virus & 9 \\
\cline { 2 - 3 } & Marburg virus & 9 \\
\cline { 2 - 3 } & Poxvirus, Vaccinia & 10,11 \\
\cline { 2 - 3 } & Cytomegalovirus & 12 \\
\cline { 2 - 3 } & Enterovirus 71 & 14 \\
\cline { 2 - 3 } & Herpes Simplex Virus Type 2 & 13 \\
\hline SARS-CoV-2 & 17 \\
\hline Intracellular bacteria & Simkania negevensis, & 16 \\
\hline & Chlamydia trachomatis & 4 \\
\hline & & 15 \\
\hline
\end{tabular}


Due to this wide variety of pathogens, and the differences in their targeted organs, Retro-2.1 would greatly benefit from a generic pharmaceutical formulation and mode of administration favouring a systemic exposition. This would allow to study Retro-2.1 in the corresponding in vivo models, and would give a starting point towards the development of a clinical formulation.

However, Retro-2.1 suffers from a low aqueous solubility (below $1 \mathrm{mg} / \mathrm{L}$ ), preventing its parenteral administration. Attempts at increasing its hydrophilicity through the introduction of hydrophilic moieties so far failed at increasing the molecule's aqueous solubility or yielded less active derivatives. On the other hand, conventional drug delivery systems such as lipidic surfactants, cyclodextrins and emulsions failed at improving Retro-2.1 solubility (unpublished results).

Recently developed drug delivery systems such as polymeric surfactants represent a potential alternative to these conventional systems. Indeed, polyether-block-polyester, and particularly poly(ethylene glycol)-block-poly(D,L)lactide (PEG-PLA) are known to efficiently dissolve hydrophobic drugs. This phenomenon is due to the spontaneous assembly of these surfactants in aqueous solution into core-shell nanostructures known as micelles. These nanoobjects possess a hydrophobic core able to host hydrophobic drugs and to shield them from the aqueous environment. The payload is then usually released in a sustained manner, despite an initial partial burst release. ${ }^{19}$ Up to date, this type of system has mostly been used to encapsulate anticancer drugs. However, PEG-PLA micelles have a great potential for systemic delivery of hydrophobic drugs such as Retro-2.1. ${ }^{20}$ As initial results led to an insufficient exposure in mice, we formulated Retro-2.1 in the chemically related PLGA-PEG-PLGA thermosensitive hydrogel which led to a sustained release and a better control of metabolism.

The present work therefore studied development of parenteral formulations of Retro-2.1 using PEG-PLA micelles and PLGA-PEG-PLGA thermosensitive hydrogels. These formulation allowed for the evaluation of Retro-2.1 pharmacological properties in vivo, starting with its pharmacokinetic parameters, as well as its metabolism. A better understanding of the drug candidate's fate in vivo could pave the way towards the conception of a generic formulation and mode of administration to evaluate its potential in numerous in vivo models. 


\section{RESULTS AND DISCUSSION}

\section{Retro-2.1 formulation in PEG-PLA micelles}

In this study, PEG-PLA with a number average molecular weight (Mn) of $4000 \mathrm{~g} / \mathrm{mol}$ (Mn(PEG) $=2000 \mathrm{~g} / \mathrm{mol} ; \mathrm{Mn}(\mathrm{PLA})=2000 \mathrm{~g} / \mathrm{mol})$ was chosen as this polymer has already been used in the past to develop the Genexol ${ }^{\circledR}$-PM, a paclitaxel formulation proved to be safe and efficient in a clinical setting. ${ }^{21,22}$ Retro-2.1 was encapsulated in PEG-PLA micelles using the thin film hydration method, also known as the solvent casting method. ${ }^{23}$ Briefly, Retro-2.1 and PEGPLA were dissolved in acetone. The solvent was then evaporated under reduced pressure and the resulting film was rehydrated using saline. The solution was finally sterile-filtered to remove any undissolved drug. Acetone was chosen because of its ability to dissolve both components, and because of its low toxicity (class 3 solvent according to the FDA). The drug concentration in the formulation was evaluated by HPLC using a standard curve (Fig. S1). This method allowed to dissolve $4.55 \mathrm{mg} / \mathrm{mL}$ of the drug in a $26.4 \mathrm{mg} / \mathrm{mL}$ PEG-PLA solution with a encapsulation yield of $91 \%$ and a drug loading of $15 \%$ calculated as described below.

$$
\begin{aligned}
& \text { encapsulation yield }=100 * \frac{m(\text { drug added })}{m(\text { drug dissolved })} \\
& \text { drug loading }=100 * \frac{m(\text { drug })}{m(\text { drug })+m(\text { polymer })}
\end{aligned}
$$

Dynamic Light Scattering (DLS) analysis of the resulting formulation revealed the presence of micelles with a mean diameter of $22.4 \mathrm{~nm}$. In comparison, empty micelles prepared in the same conditions had a mean diameter of $20.6 \mathrm{~nm}$ (Fig. S2).

The formulation was evaluated to be stable at $4{ }^{\circ} \mathrm{C}$ and $-20{ }^{\circ} \mathrm{C}$ for $48 \mathrm{~h}$ and was able to withstand at least one freeze/thaw cycle without any payload leak. However, about $35 \%$ of the drug load precipitated upon storage at room temperature for 24 hours (Fig. S3). Every subsequent formulation was therefore stored at $-20{ }^{\circ} \mathrm{C}$ and thawed at $4{ }^{\circ} \mathrm{C}$ before use. 
The ability of the formulation to release Retro- 2.1 in a sustained fashion was estimated by the dialysis method at room temperature. The detailed procedure can be found in the experimental part. Although this model has been recognized as suboptimal to predict the sustained-release properties of a system in vivo, it can give precious information on the interactions between the drug and the carrier. ${ }^{24}$ In this setting, a burst release of about $18 \%$ of the payload was observed in the first 40 minutes, followed by a slow release of about $5 \%$ of the payload in the following 6 hours (Fig. 2). After 6.5 hours, a precipitate started appearing in the dialysis bag and the experiment was stopped. These data should be considered with precaution, as several studies showed that lipophilic drugs are quickly released from PEG-PLA micelles and then adsorbed on plasmatic proteins following an intravenous injection. ${ }^{20,25}$

Figure 2. Release kinetic of Retro-2.1 out of PEG-PLA micelles in PBS at room temperature.

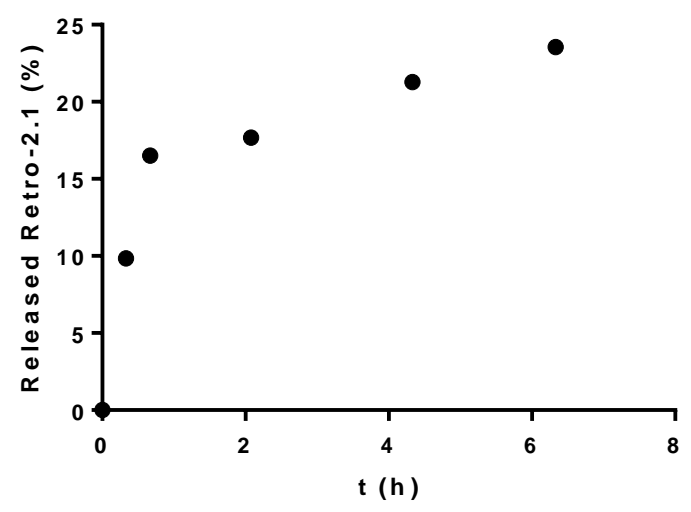

Pharmacokinetic study following the parenteral administration of Retro-2.1 formulated in PEG-PLA.

In order to better understand the fate of Retro-2.1 formulated in PEG-PLA following its parenteral administration in vivo, a pharmacokinetic study was performed on mice. For this purpose, a Liquid Chromatography coupled to tandem Mass Spectrometry (LC-MS/MS) quantitation method of Retro-2.1 in mouse plasma was developped and validated. As intravenous (IV) injections are closer to the eventual route of administration in a clinical setting, this route was chosen as a starting point. However, since intraperitoneal (IP) injections are closer to the reality of preclinical studies due to their simplicity, this route was also investigated. In both cases, the formulation was injected at a Retro- 2.1 dose of $2 \mathrm{mg} / \mathrm{kg}$. At different timepoints over 24 hours, a blood sample was drawn and centrifuged to isolate the plasma which was titrated. The plasmatic concentration of Retro- 2.1 was plotted as a function of time and the 
corresponding pharmacokinetic parameters were calculated using a non-compartmental model (Fig. 3). Of note, no sign of pain or acute toxicity were observed in mice over 24 hours after administration of the formulation.

Figure 3. A. Retro-2.1 plasmatic concentration following IV or IP injection of $2 \mathrm{mg} / \mathrm{kg}$ to mice (IV: $n=3 /$ timepoint, IP: $n=5 /$ timepoint). Results are presented as mean, error bars represent standard deviation. Timepoints: $5 \mathrm{~min}, 15 \mathrm{~min}, 30 \mathrm{~min}, 1 \mathrm{~h}, 2 \mathrm{~h}, 4 \mathrm{~h}, 7 \mathrm{~h}, 24 \mathrm{~h}$ (not shown). B. Corresponding pharmacokinetic parameters. $C_{\max }$ : maximal concentration observed, $T_{\max }: C_{\max }=$ corresponding timepoint, $A U C_{\text {tot }}$ : area under curve taking into account the extrapolated AUC,

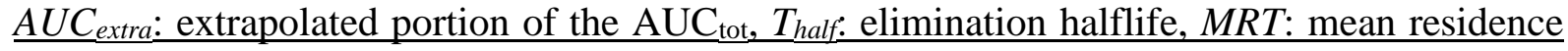
time, $C L$ : apparent total body clearance of Retro- 2.1 from plasma ( $F$ : absorbed fraction), $V_{S S}$ : distibution volume at steady state.

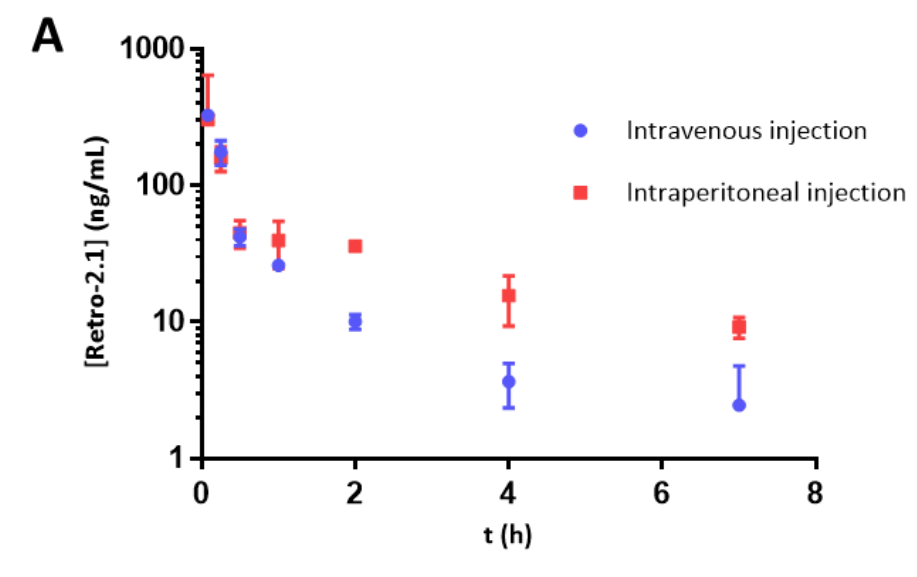

\section{B}

\begin{tabular}{|c|c|c|c|c|c|c|c|c|}
\hline & \multicolumn{8}{|c|}{ Parameter } \\
\hline & $\mathrm{C}_{\max }$ & $\mathrm{T}_{\max }$ & $A U C_{\text {tot }}$ & $\mathrm{AUC}_{\text {extra }}$ & $\mathrm{T}_{\text {half }}$ & MRT & $\mathrm{CL}$ & $\mathrm{V}_{\mathrm{SS}}$ \\
\hline $\begin{array}{l}\text { Administration } \\
\text { route }\end{array}$ & $\mathrm{ng} \cdot \mathrm{mL}^{-1}$ & $\mathrm{~h}$ & $\mathrm{ng} \cdot \mathrm{mL}^{-1} \cdot \mathrm{h}$ & $\%$ & $\mathrm{~h}$ & $\mathrm{~h}$ & $\mathrm{~mL} \cdot \mathrm{min}^{-1} \cdot \mathrm{kg}^{-1}$ & L. $\mathrm{kg}^{-1}$ \\
\hline Intravenous & 327.7 & 0.0833 & 212.8 & 2.3 & 6.7 & 2.9 & 156.6 & 27.5 \\
\hline Intraperitoneal & 304.3 & 0.0833 & 322.23 & 2.1 & 5.0 & 4.2 & $103.4(\mathrm{CL} / \mathrm{F})$ & 26.3 \\
\hline
\end{tabular}

In both cases, Retro-2.1 was eliminated moderatly quickly from the blood circulation withelimination half lives of 6.7 and 5.0 hours for IV and IP injection respectively. The low maximal concentrations $\left(\mathrm{C}_{\max }\right)$, Areas Under Curve (AUC) and high clearances are representative of an unsatisfying systemic exposure with Retro-2.1. Indeed, the plasmatic concentrations of Retro-2.1 seven hours following IV or IP injection were found to be 6 and 21 $\mathrm{nM}$ respectively. For comparative purposes, the half maximal effective concentration $\left(\mathrm{EC}_{50}\right)$ of Retro-2.1 against the Shiga toxin, describing the compound concentration needed to achieve $50 \%$ of its maximal protection effect was found to be $102 \mathrm{nM}$ for the racemic mixture $(54 \mathrm{nM}$ for the $(S)$ enantiomer). ${ }^{3}$ One can thus infer that the plasmatic concentrations achieved using this formulation and this administration route will not lead to a clinically relevant exposition. 
The unusual similarity between the two pharmacokinetic profiles (Fig. 3A) and pharmacokinetic parameter sets (Fig. 3B) may be due to two separate phenomena. First, an extremely fast elimination or distribution of the drug out of the blood circulation when the formulation is injected IV would greatly affect the total Area Under Curve (AUC tot) through underestimation of the extrapolated AUC. Secondly, the intraperitoneal cavity could act as a reservoir from which the drug would be slowly absorbed into the blood stream, thus compensating a fast plasmatic elimination. This would partly explain why the $\mathrm{AUC}_{\text {tot }}$ is counterintuitively lower when the formulation is injected IV. This comparison also shows that the IP and IV routes lead to similar expositions to the drug.

These results revealed that both IV and IP injections lead to a relatively fast elimination of Retro-2.1 from the bloodstream. A biodistribution study using a radiolabeled drug would be required to precisely determine the fate of the drug following its elimination from the plasma. Nonetheless, these pharmacokinetic parameters are suboptimal to yield a sustained and systemic exposition to the drug, which would be required in most preclinical and clinical applications.

\section{Metabolism of Retro-2.1 in vitro}

A better understanding of the fate of Retro-2.1 following its administration in vivo could help designing systems able to achieve greater and more sustained systemic expositions. As discussed above, a biodistribution study would indicate if Retro-2.1 is distributed in the tissue and in which tissue it preferentially accumulates, or if it is eliminated through renal or biliary excretion. However, this study would require the radiolabeling of the drug and its subsequent formulation and administration in vivo, which represent a considerable challenge. Moreover, this study would not indicate if Retro- 2.1 is distributed and excreted under an unchanged form, or if it is metabolized over time. However, a fast metabolism of Retro-2.1 could contribute greatly to its fast elimination from the blood stream.

The study of a drug metabolism is crucial as this process can lead to a faster renal elimination through hydrophilicity enhancement. This phenomenon can also lead to a loss or exhaltation of the drug's biological activity, or to the generation of toxic metabolites. ${ }^{26}$

As a first step, in order to evaluate Retro-2.1 metabolic stability, the drug was incubated with mouse and human hepatic microsomes, a hepatocyte fraction containing high concentrations of 
CYP450, the main enzymes responsible for drug metabolism. ${ }^{27}$ Retro- 2.1 concentration in the samples was determined by LCMS following 45 minutes of incubation.

Table 2. Metabolic stability of Retro-2.1 upon incubation with mouse or human microsomes.

\begin{tabular}{|c|c|c|c|}
\hline & $\begin{array}{c}\text { Metabolic } \\
\text { stability at } \mathbf{~}= \\
\mathbf{4 5} \text { min } \\
\%\end{array}$ & $\begin{array}{c}\mu \mathrm{CL} \cdot \mathrm{min}^{-1} \cdot \mathrm{mg} \text { of } \\
\mathrm{protein}^{-1}\end{array}$ & $\begin{array}{c}\text { Non-NADPH } \\
\text { degradation } \\
(\mathbf{\%})\end{array}$ \\
\hline Mouse & 2.4 & 460 & $<5$ \\
\hline Human & 27.4 & 27.8 & $<5$ \\
\hline
\end{tabular}

This preliminary study revealed that Retro-2.1 is quickly metabolised by both human and mouse microsomes. Following 45 minutes of incubation with mouse microsomes, only about $2 \%$ of Retro-2.1 was found unchanged, indicating a particularly fast metabolism. The non-NADPH degradation was found to be negligible, indicating that the metabolism is mediated by CYP450. These results potentially explain the fast disappearance of Retro-2.1 from the bloodstream following its administration in mice.

To further characterize the generated metabolites, the experiment with mouse microsomes was repeated and the mass spectrum of the extracted metabolites was followed over time. The molecular mass of the metabolites was determined and the intensity of the corresponding chromatographic peaks were plotted as a function of time (Fig. 4).

Figure 4. Normalized peak area of Retro-2.1 metabolites obtained following an incubation of Retro-2.1 with mouse microsomes and analysed by LC-MS.

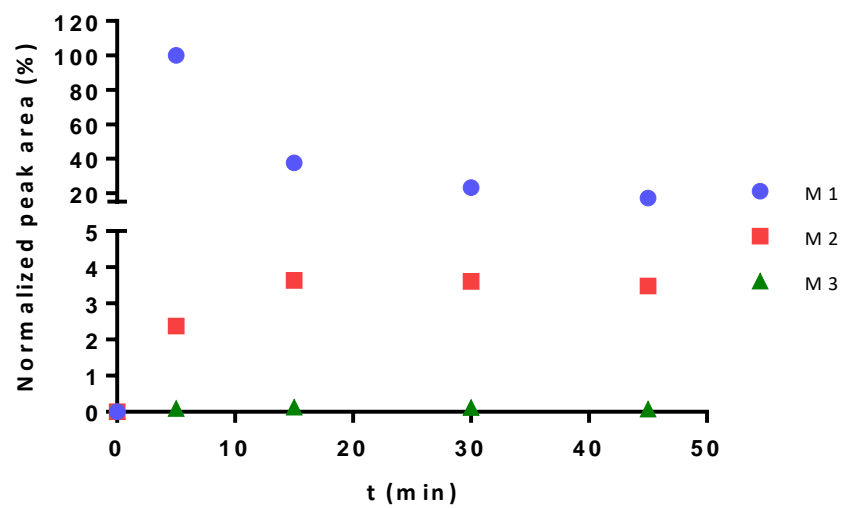


Three metabolites noted M1, M2 and M3 with respective increments of 16, 32 and $48 \mathrm{~g} / \mathrm{mol}$ in regard to Retro-2.1 molecular weight were detected. These mass increments indicates that the incubation of Retro- 2.1 with mouse microsomes leads to respectively one, two and three oxydations of the molecule. Given that the maximum peak area of M2 and M3 is only a fraction of the minimum peak area of M1, M2 and M3 were neglected at this stage. Of note, similar results were obtained with human microsomes, although only two metabolites with molecular weight increments of 16 and $32 \mathrm{~g} / \mathrm{mol}$ were detected (F. S4).

In order to localize the metabolization site on Retro-2.1, the parent drug and the sample obtained after 5 minutes of incubation with mouse microsomes were analysed by LC-MS/MS. This method led to the identification of 6 fragments for Retro-2.1, noted F1 to F6 (Fig. 5, black fragments). In the case of M1, fragment F1 to F6 were obtained, as well as 4 new fragments (Fig. 5, blue fragments) corresponding to fragments F1, F4, F5 and F6 with mass increments of about $16 \mathrm{~g} / \mathrm{mol}$.

Figure 5. Retro-2.1 and M1 fragmentation patterns obtained by MS/MS. Fragments annoted in black are common to both molecules. Fragments annoted in blue were only observed for M1. For each fragment, only the experimental mass was annoted.

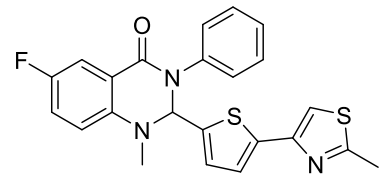

Retro-2.1

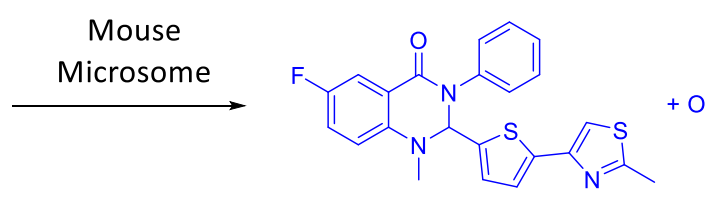

M1

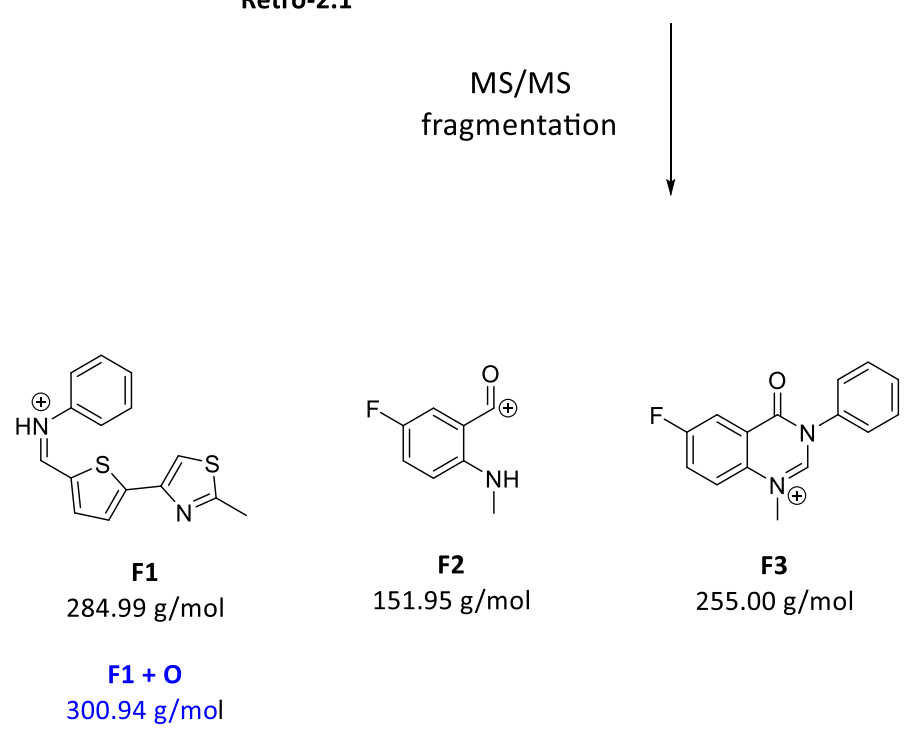

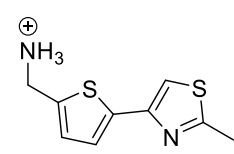

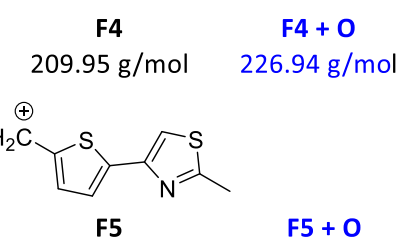

$194.01 \mathrm{~g} / \mathrm{mol} \quad 209.87 \mathrm{~g} / \mathrm{mol}$

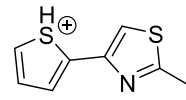

F6

$181.98 \mathrm{~g} / \mathrm{mol}$
$\mathrm{F} 6+\mathrm{O}$ $197.83 \mathrm{~g} / \mathrm{mol}$ 
This experiment shows that M1 is obtained by oxydation of Retro-2.1 thiophene-thiazole moiety. It is well known that one of the preferential modes of CYP450-mediated drug oxydation occurs via C-sp3 hydroxylation. ${ }^{28}$ Such a process would yield a derivative noted MM176B (Fig. 6). Fortunately, this compound was previously synthesized in our group as an intermediate in the design of a molecular probe during the search for Retro-2.1 intracellular target ${ }^{18}$ (synthetic route available in the supporting information). The comparison of the retention time and fragmentation pattern of M1 and MM176B by LC-MS/MS confirmed the identity of this derivative as Retro-2.1 major metabolite. Of note, MM176B was also found to be the major metabolite observed following incubation of Retro-2.1 on human microsomes.

Figure 6. Structure of Retro-2.1 major metabolite, MM176B.

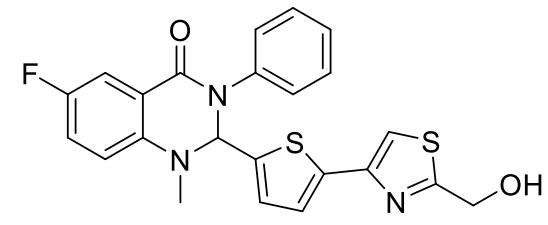

\section{Metabolism of Retro-2.1 in vivo}

The results obtained in vitro were confirmed by a second pharmacokinetic study. Retro-2.1 formulated in PEG-PLA was injected IP at a dose of $50 \mathrm{mg} / \mathrm{kg}$ to mice, as it is the maximum dose achievable for an injection volume of about $0.2 \mathrm{~mL}$. Blood samples were drawn at the same time intervals as previously described in this manuscript. Retro-2.1 and MM176B plasmatic concentrations were determined by LC-MS/MS using an internal calibration method and plotted against time (Fig. 7). Of note, no apparent sign of pain of acute toxicity were observed over $24 \mathrm{~h}$ following the administration of the formulation. 
Figure 7. A. Pharmacokinetic profile of Retro-2.1 and its major metabolite MM176B following the IP injection of $50 \mathrm{mg} / \mathrm{kg}$ of Retro- 2.1 formulated in PEG-PLA ( $\mathrm{n}=3$ mice/timepoint). Results are presented as mean, error bars represent standard deviation. Timepoints: 5 min, 15 min, 30 min, 1 h, 2 h, 4 h, 7 h, 24 h. B. Plasmatic concentration ratio between Retro-2.1 and MM176B over time. C. Corresponding pharmacokinetic parameters. $C_{\max }$ : maximal concentration observed, $T_{\max }$ : $C_{\max }$-corresponding timepoint, $A U C_{\text {tot }}$ : area under curve taking into account the extrapolated AUC, $A U C_{\text {extra }}$ : extrapolated portion of the $\mathrm{AUC}_{\text {tot }}, T_{\text {half }}$ : elimination halflife, $M R T$ : mean residence time, $C L$ : apparent total body clearance of Retro-2.1 from plasma ( $F$ : absorbed fraction), $V_{S S}$ : distribution volume at steady state.
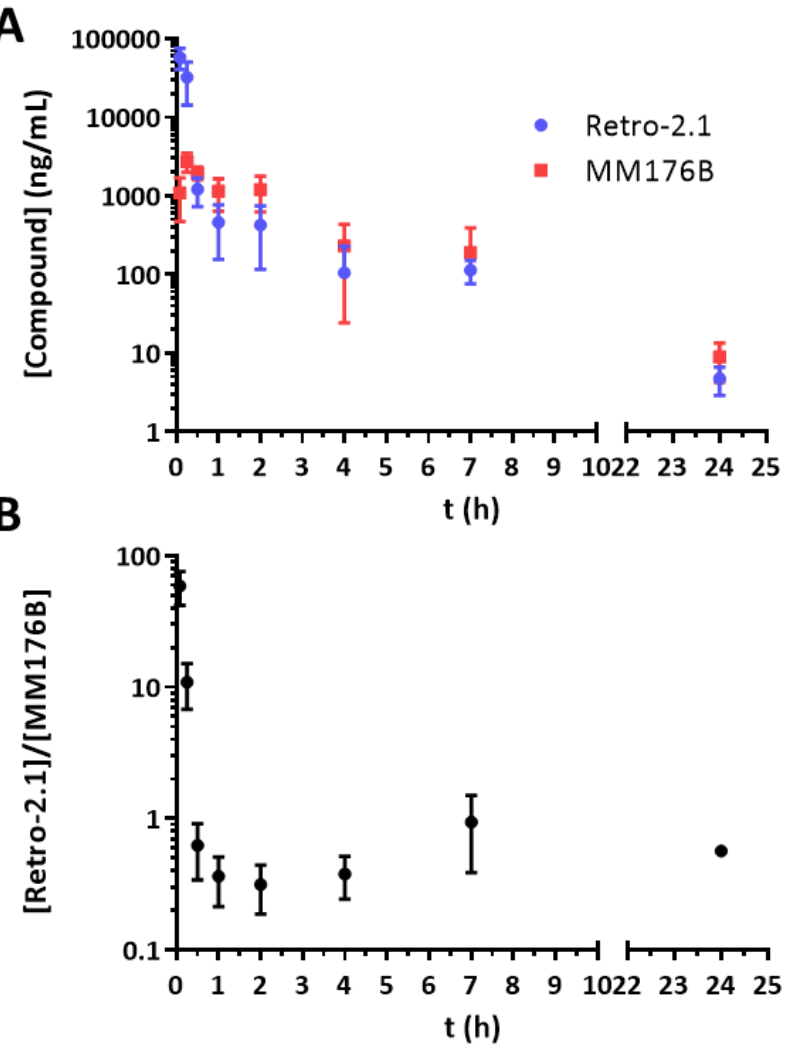

\begin{tabular}{|c|c|c|c|c|c|c|c|c|}
\hline & \multicolumn{8}{|c|}{ Parameter } \\
\hline & $C_{\max }$ & $\mathrm{T}_{\max }$ & $A \cup C_{\text {tot }}$ & $A U C_{\text {extra }}$ & $T_{\text {half }}$ & MRT & $\mathrm{CL} / \mathrm{F}$ & $\mathrm{V}_{\mathrm{SS}}$ \\
\hline & $\mathrm{ng} \cdot \mathrm{mL}^{-1}$ & $\mathrm{~h}$ & $\mathrm{ng} \cdot \mathrm{mL}^{-1} \cdot \mathrm{h}$ & $\%$ & $\mathrm{~h}$ & $\mathrm{~h}$ & $\mathrm{~mL} \cdot \mathrm{min}^{-1} \cdot \mathrm{kg}^{-1}$ & L. $\mathrm{kg}^{-1}$ \\
\hline Retro-2.1 & 50591 & 0.0833 & 18503 & 0.1 & 3.3 & 1.0 & 45 & 2.8 \\
\hline MM176B & 2758 & 0.25 & 6704 & 0.4 & 3.7 & 3.43 & & \\
\hline
\end{tabular}

As shown in Fig. 7A, Retro-2.1 is indeed metabolized into derivative MM176B in mice. In fact, only 30 minutes after injection, the plasmatic concentration ratio between Retro-2.1 and MM176B (Fig. 7B) droped below 1. Although Retro-2.1 $\mathrm{C}_{\max }$ and AUC are considerably higher than previously with an injected dose of $2 \mathrm{mg} / \mathrm{kg}$, the $\mathrm{T}_{\text {half }}$ and MRT remain particularly low. These results confirm that Retro- 2.1 metabolism can partly explain its fast plasmatic 
elimination. At this stage, we therefore thought important to compare Retro-2.1 and MM176B biological activity in vitro.

Retro-2.1 and MM176B biological activity were evaluated using a Shiga toxin-1 (Stx-1) intoxication assay as described previously. ${ }^{1-3}$ This assay measures the ability of a test compound to protect HeLa cells against the inhbition of protein biosynthesis induced by increasing concentrations of Stx-1 (see the experimental part for more information). The half maximal effective concentration $\left(\mathrm{EC}_{50}\right)$ describes the test compound concentration needed to achieve $50 \%$ of the maximal protection effect it can provide. In this assay, Retro-2.1 and MM176B had $\mathrm{EC}_{50}$ values of 90 and $7381 \mathrm{nM}$ respectively. Of note, the $\mathrm{EC}_{50}$ of Retro-2.1 was in accordance with reported values. ${ }^{3}$

Following its IP and IV administration to mice, Retro-2.1 is quickly metabolised into an 80 times less potent hydroxylated derivative. This could be a significant obstacle for Retro-2.1 preclinical evaluation. One way to improve this pharmacological profile would be to achieve a sustained release of Retro- 2.1 while protecting the drug from its metabolism in the liver. A subcutaneous (SC) administration of an appropriate formulation of Retro-2.1 could help to fulfill these goals.

\section{Formulation of Retro-2.1 in a biocompatible polymer-based thermosensitive hydrogel.}

In the late 1990s, it was discovered that aqueous solutions of the triblock copolymer poly(ethylene glycol)-block-poly((D,L)lactide-co-glycolide)-block-poly(ethylene glycol) (PEG-PLGA-PEG) form free flowing solutions at room temperature and hydrogels upon heating. ${ }^{29}$ It was later found that the copolymer PLGA-PEG-PLGA, which is more convenient to prepare, gives the same results. By tuning the polymer composition, it is possible to obtain an injectable solution, that spontaneously gelify at body temperature, forming an implant able to release the drug in a sustained fashion. Such polymers are reported to be biocompatible, bioresorbable and have already proven to yield a sustained-release of the encapsulated drug following a SC administration. ${ }^{29,30}$ Considering the structural proximity to PEG-PLA, and the ability of the latter to dissolve Retro-2.1 we hypothesized this polymer would be applicable to this drug candidate.

Based on data from the litterature, a PLGA-PEG-PLGA polymer was synthesized via ringopening polymerization of a mixture of lactide and glycolide initiated by poly(ethylene glycol) 
$(\mathrm{Mn}=1450 \mathrm{~g} / \mathrm{mol})$ and catalyzed by tin ethyl hexanoate. ${ }^{31}$ The polymer was characterized by NMR spectrometry (Fig. S6) and Gel Permeation Chromatography (GPC, Fig. S7). The polymer characteristics are presented in Table 3.

Table 3. Synthesized PLGA-PEG-PLGA polymer characteristics. ${ }^{a}$ As determined by ${ }^{1} \mathrm{H}-\mathrm{NMR}$. bAs determined by GPC. LA/GA: lactide to glycolide molar ratio, Mn: number average molecular weight, Mw: weight average molecular weight

\begin{tabular}{|ccccccc|}
$\begin{array}{c}\text { Mn (PEG) } \\
(\mathbf{g} / \mathbf{m o l})\end{array}$ & $\begin{array}{c}\mathbf{M n}^{\mathbf{a}} \\
(\mathbf{g} / \mathbf{m o l})\end{array}$ & $\begin{array}{c}\text { LA/GA } \\
\text { theoretical }\end{array}$ & $\begin{array}{c}\text { LA/GA } \\
\text { experimental }^{\mathbf{a}}\end{array}$ & $\begin{array}{c}\mathbf{M n}^{\mathbf{b}} \\
(\mathbf{g} / \mathbf{m o l})\end{array}$ & $\begin{array}{c}\mathbf{M w}^{\mathbf{b}} \\
(\mathbf{g} / \mathbf{m o l})\end{array}$ & Polydispersity $^{\mathbf{b}}$ \\
\hline 1450 & 4976 & 4.32 & 4.7 & 4205 & 4969 & 1.182 \\
\hline
\end{tabular}

The thin-film rehydration technique was also used to formulate Retro-2.1 in PLGA-PEG-PLGA, using acetone as a dissolution solvent and saline as a rehydration vehicle.

A $20 \%$ (w/v) solution of this polymer in saline was able to stably dissolve $3.25 \mathrm{mg} / \mathrm{mL}$ of Retro2.1 , with an encapsulation yield of $98 \%$ and a drug loading of $1.9 \%$. A DLS analysis of the formulation revealed the presence of micelles with a mean diameter of $24.1 \mathrm{~nm}(23.1 \mathrm{~nm}$ for empty micelles, Fig. S8). The inverted flask method showed that the formulation forms a freeflowing solution at room temperature and starts gelating at $31{ }^{\circ} \mathrm{C}$ which is suitable for our purpose. Of note, above $42{ }^{\circ} \mathrm{C}$, the polymer aggregates and separates from water, which is in accordance with other reported polymers with similar structures. ${ }^{31}$ The formulation was stable for at least 13 days when stored at $4{ }^{\circ} \mathrm{C}$. However, like the formulation in PEG-PLA, the formulation in PLGA-PEG-PLGA lost $20 \%$ of its payload upon storage at $25{ }^{\circ} \mathrm{C}$ for $24 \mathrm{~h}$ (Fig. S9). Subsequent formulations were therefore freshly prepared and stored at $4{ }^{\circ} \mathrm{C}$ before use.

\section{Pharmacokinetic study following the SC administration of Retro-2.1 in a PLGA-PEG- PLGA-based thermosensitive hydrogel.}

A pharmacokinetic study was performed as previously described in this manuscript. The formulation was injected to mice subcutaneously, in the back, at a dose of $25 \mathrm{mg} / \mathrm{kg}$ of Retro2.1, which is the maximum dose achievable with an injection volume of about $0.15 \mathrm{~mL}$. The plasmatic concentration of Retro-2.1 and its metabolite MM176B were plotted as a function of time and the corresponding pharmacokinetic parameters were calculated as previously (Fig. 8). Of note, no sign of pain or acute toxicity were observed over 48 hours after injection. 
Figure 8. A. Retro-2.1 and MM176B plasmatic concentrations following SC injection of 25 $\mathrm{mg} / \mathrm{kg}$ of Retro- 2.1 formulated in PLGA-PEG-PLGA to mice ( $\mathrm{n}=5 /$ timepoint). Results are presented as mean, error bars represent standard deviation. Timepoints: $5 \mathrm{~min}, 30 \mathrm{~min}, 1 \mathrm{~h}, 2 \mathrm{~h}$, 4 h, 7 h, 24 h, 48 h. B. Plasmatic concentration ratio between Retro-2.1 and MM176B over time C. Corresponding pharmacokinetic parameters. $C_{\max }$ : maximal concentration observed, $\underline{T_{\max }}: C_{\max }$-corresponding timepoint, $A U C_{t o t}$ : area under curve taking into account the extrapolated AUC, $A U C_{\text {extra: }}$ extrapolated portion of the $\mathrm{AUC}_{\text {tot }}, T_{\text {half }}$. elimination halflife, $M R T$ : mean residence time, $C L$ : apparent total body clearance of Retro-2.1 from plasma ( $F$ : absorbed fraction), $V_{S S}$ : distribution volume at steady state.

A

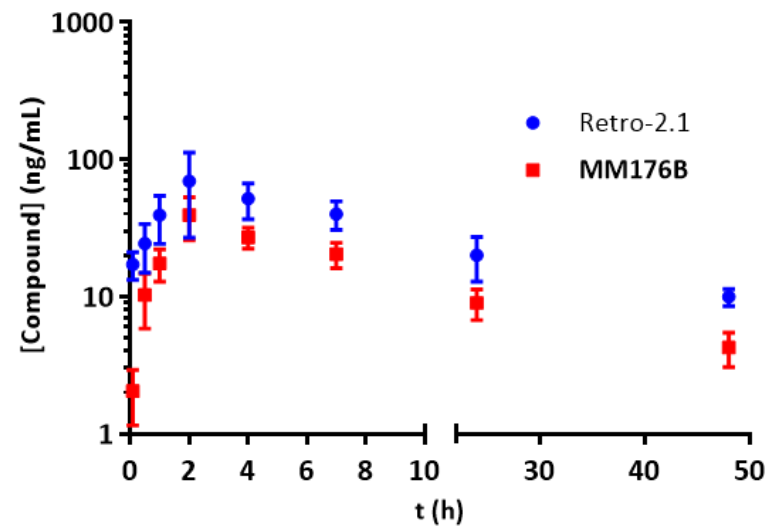

B

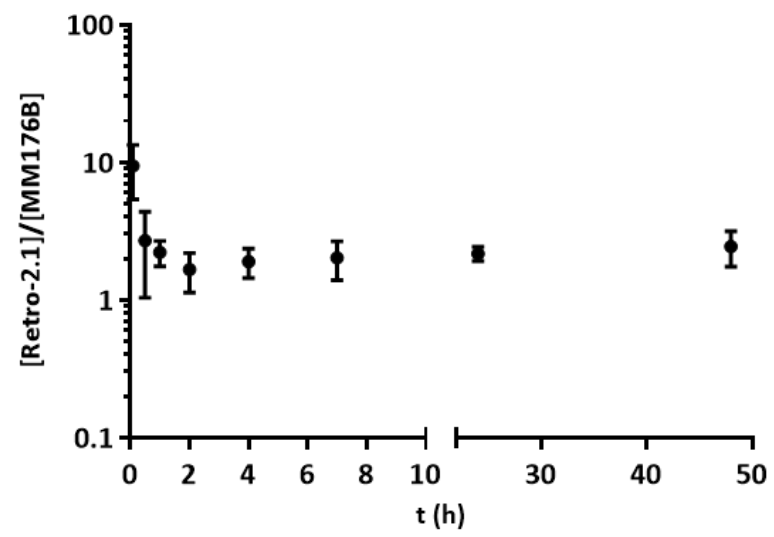

C

$\mathrm{t}(\mathrm{h})$

\begin{tabular}{|ccccccccc|} 
& \multicolumn{10}{c|}{ Parameter } \\
& $\mathrm{C}_{\max }$ & $\mathrm{T}_{\text {max }}$ & $\mathrm{AUC}$ tot & $\mathrm{AUC}_{\text {extra }}$ & $\mathrm{T}_{\text {half }}$ & $\mathrm{MRT}$ & $\mathrm{CL} / \mathrm{F}$ & $\mathrm{V}_{\mathrm{sS}}$ \\
\hline Retro-2.1 & $\mathrm{ng} \cdot \mathrm{mL}^{-1}$ & $\mathrm{~h}$ & $\mathrm{ng} \cdot \mathrm{mL}^{-1} \cdot \mathrm{h}$ & $\%$ & $\mathrm{~h}$ & $\mathrm{~h}$ & $\mathrm{~mL} \cdot \mathrm{min}^{-1} \cdot \mathrm{kg}^{-1}$ & $\mathrm{~L} \cdot \mathrm{kg}^{-1}$ \\
\hline MM176B & 75.2 & 2 & 1416 & 17 & 19 & 26 & 294 & 456 \\
\hline
\end{tabular}

As shown in Fig. 8A, this formulation associated to this mode of administration yielded a sustained-release of Retro-2.1 for at least 48 hours, whereas the compound was barely detectable 24 hours after intraperitoneal injection of twice the dose. Although the AUC is significantly lower than when Retro- 2.1 was injected IP at a dose of $50 \mathrm{mg} / \mathrm{kg}$, the $\mathrm{T}_{\text {half }}$ in these conditions was almost 6 times higher. Moreover, the plasmatic concentration ratio between 
Retro-2.1 and MM176B remained around 2 from 30 minutes after administration to the end of the experiment (Fig.8B). This mode of administration therefore provides a good alternative to the parenteral administration of Retro- 2.1 formulated in PEG-PLA by providing a sustained release and a better control of the drug metabolism.

\section{CONCLUSIONS}

Where classical drug delivery vehicles failed, polymeric surfactants proved useful in improving Retro-2.1 solubility in aqueous media, and allowed the evaluation of its pharmacokinetic and metabolic profiles following parenteral administration. Although a lot is yet to discover on Retro-2.1 metabolism (nature of the implicated CYP450 and phase II metabolism), this first study allowed us to obtain an efficient SC formulation using a PLGA-PEG-PLGA-based injectable implant. This formulation with its mode of administration unlocks further studies of the pharmaceutical potential of Retro- 2.1 in vivo. 


\section{EXPERIMENTAL SECTION}

\section{Materials}

Reagents and solvents were purchased from Sigma Aldrich, VWR, Acros Organics, Merck or Apollo Scientific and used without further purification unless otherwise indicated. PEG-PLA $(\mathrm{Mn}(\mathrm{PEG})=2000 \mathrm{~g} / \mathrm{mol}, \mathrm{Mn}(\mathrm{PLA})=2000 \mathrm{~g} / \mathrm{mol})$ were purchased from Sigma Aldrich. Dichloromethane (DCM) was distilled over $\mathrm{CaH}_{2}$ before use. Reactions requiring anhydrous conditions were performed under an argon atmosphere in flame-dried glassware. Reactions under microwave irradiation were performed on an Intellivent Explorer microwave reactor (CEM). Reactions were followed by thin-layer chromatography using precoated TLC silica gel 60 F254 and organic compounds were visualized by UV light (254 nm or $360 \mathrm{~nm}$ ) or after immersion in a $\mathrm{KMnO}_{4} / \mathrm{K}_{2} \mathrm{CO}_{3}$ bath followed by heating. Purifications by column chromatography were performed using Silica Gel 60 (0.040 - $063 \mathrm{~mm})$.

\section{Instrumentation and methods}

\section{NMR Spectrometry}

${ }^{1} \mathrm{H}$ and ${ }^{13} \mathrm{C}$ NMR spectra were recorded on a Bruker Avance 400 Ultrashield at room temperature at $400 \mathrm{MHz}$ and $100 \mathrm{MHz}$ respectively and analyzed with the MestRenova software. Chemical shifts were calibrated using residual undeuterated chloroform in $\mathrm{CDCl}_{3}(\delta$ $\mathrm{H}=7.26 \mathrm{ppm}, \delta \mathrm{C}=77.2 \mathrm{ppm})$ or DMSO in DMSO- $d 6(\delta \mathrm{H}=2.50 \mathrm{ppm}, \delta \mathrm{H}=39.5 \mathrm{ppm})$ and are reported in parts per million (ppm) and coupling constants are reported in Hertz $(\mathrm{Hz})$. Splitting patterns are designed as singlet (s) or broad singlet (bs), doublet (d), triplet (t), quartet (q), quintet (quin) and multiplet (m).

\section{HPLC}

HPLC analyses were performed using a Shimadzu system equipped with a degasser (DEGASYS DG-1310), a system controller (Shimadzu SCL-10A VP), a binary pump system (Shimadzu LC-10AT VP), and an UV-Vis detector (Shimadzu SPD-10A VP). Compounds were separated using an ACE Excel 3 SuperC18 (100x4.6 mm) column at room temperature. Absorbance spectra at $300 \mathrm{~nm}$ were recorded using the Borwin software. 


\section{Gradient}

\begin{tabular}{|ccccc|}
\hline Time $(\mathrm{min})$ & Flow rate $(\mathrm{mL} / \mathrm{min})$ & $\% \mathrm{~A}$ & $\% \mathrm{~B}$ & Curve \\
\hline Initial & 1.0 & 95 & 5 & Initial \\
\hline 8.50 & 1.0 & 0 & 100 & Linear \\
\hline 9.50 & 1.0 & 0 & 100 & Linear \\
\hline
\end{tabular}

Solvent A: MilliQ water

Solvent B: MeCN

\section{Low-resolution mass spectrometry}

UPLC-MS analyses were performed using a Waters system equipped with a BEH Xbridge C18 $(50 \times 2.1 \mathrm{~mm} ; 1.7 \mu \mathrm{m})$ column set at $40^{\circ} \mathrm{C}$, an ELSD detector (SEDEX 75, SEDERE) and a diode array detector (Acquity PDA e $\lambda$ Detector) coupled to a simple quadrupole detector (SQ Detector 2). Mass spectra were recorded in both positive and negative ion mode in the $\mathrm{m} / \mathrm{z}$. 1002,000 range and treated with the Masslynx software. ESI source parameters and gradient are described below:

\section{Source parameters}

\begin{tabular}{|ll|}
\hline Parameter & Value \\
\hline Capillary $(\mathrm{kV})$ & 3.5 \\
\hline Source temperature $\left({ }^{\circ} \mathrm{C}\right)$ & 150 \\
\hline Desolvation temperature $\left({ }^{\circ} \mathrm{C}\right)$ & 200 \\
\hline Cone gas flow $(\mathrm{L} / \mathrm{h})$ & 20 \\
\hline Desolvation gas flow $(\mathrm{L} / \mathrm{h})$ & 650 \\
\hline
\end{tabular}

\section{Gradient}

\begin{tabular}{|llccc|}
\hline Time $(\mathrm{min})$ & Flow rate $(\mathrm{mL} / \mathrm{min})$ & $\% \mathrm{~A}$ & $\% \mathrm{~B}$ & Curve \\
\hline Initial & 0.4 & 95 & 5 & Initial \\
\hline 3.00 & 0.4 & 0 & 100 & Linear \\
\hline 4.00 & 0.6 & 0 & 100 & Linear \\
\hline
\end{tabular}

Solvent A: MilliQ water $+0.1 \% \mathrm{HCO}_{2} \mathrm{H}$

Solvent B: $\mathrm{MeCN}+0.1 \% \mathrm{HCO}_{2} \mathrm{H}$ 


\section{LC-MS/MS}

LC-MS/MS analyses were performed using a Waters ACQUITY UPLC ${ }^{\circledR}$ system equipped with a BEH C18 $(100 \times 2.1 \mathrm{~mm} ; 1.7 \mu \mathrm{m})$ column set at $50{ }^{\circ} \mathrm{C}$, coupled to a XEVO TQ-S (Waters) mass spectrometer operating in positive ion electrospray Multiple Reaction Monitoring mode. ESI source parameters and gradient are described below:

\section{Source parameters}

\begin{tabular}{|cc|}
\hline Parameter & Value \\
\hline Capillary $(\mathrm{kV})$ & 3 \\
\hline Source temperature $\left({ }^{\circ} \mathrm{C}\right)$ & 150 \\
\hline Desolvation temperature $\left({ }^{\circ} \mathrm{C}\right)$ & 650 \\
\hline Cone gas flow $(\mathrm{L} / \mathrm{h})$ & 150 \\
\hline Desolvation gas flow $(\mathrm{L} / \mathrm{h})$ & 1200 \\
\hline Collision gas flow $(\mathrm{mL} / \mathrm{min})$ & 0.15 \\
\hline
\end{tabular}

\section{Gradient}

\begin{tabular}{|ccccc|}
\hline Time $(\mathrm{min})$ & Flow rate $(\mathrm{mL} / \mathrm{min})$ & $\% \mathbf{A}$ & $\% \mathrm{~B}$ & Curve \\
\hline Initial & 0.6 & 80 & 20 & Initial \\
\hline 1 & 0.6 & 80 & 20 & Linear \\
\hline 18 & 0.6 & 50 & 50 & Linear \\
\hline 18.01 & 0.6 & 0 & 100 & Linear \\
\hline 18.50 & 0.6 & 0 & 100 & Linear \\
\hline 18.51 & 0.6 & 80 & 20 & Linear \\
\hline 25 & 0.6 & 80 & 20 & Linear \\
\hline
\end{tabular}

Solvent A: MilliQ water $+0.1 \% \mathrm{HCO}_{2} \mathrm{H}$

Solvent B: $\mathrm{MeCN}+0.1 \% \mathrm{HCO}_{2} \mathrm{H}$

\section{Infrared Spectrometry}

Infrared spectra were acquired with a Spectrum 2 FT-IR spectrometer (PerkinElmer) and recorded using the PerkinElmer Spectrum software. 


\section{Dynamic Light Scattering}

Dynamic Light Scattering experiments were performed using a Vasco Flex particle size Analyzer equipped with a $450 \mathrm{~nm}$ Laser. Data were recorded at $20^{\circ} \mathrm{C}$ using a refractive index of 1.331 and a solvent viscosity of $0.982 \mathrm{cP}$. For each sample, 10 acquisitions were realized using a noise limit of $1 \%$ and 200 channels with a time interval of $1 \mu \mathrm{s}$. All samples were analyzed at a concentration of $10 \mathrm{mg} / \mathrm{mL}$ in $4 \mathrm{~mL}$ glass vials (Lab File, Wheaton) unless otherwise noted and filtered on a $0.2 \mu \mathrm{m}$ membrane $\left(\right.$ Millex $\left.^{\circledR}\right)$ before analysis.

\section{Gel Permeation Chromatography}

The number average molecular weight (Mn), the weight average molecular weight (Mw), and the polydispersity of the synthesized PLGA-PEG-PLGA were determined using a GPC 220 system from PolymerLabs (Agilent Technologies) in THF at $35^{\circ} \mathrm{C}$, with a flow rate of $1 \mathrm{~mL} / \mathrm{min}$ equipped with a series of two $7.5 \mathrm{~mm}$ diameter x $300 \mathrm{~mm}$ Polymer Labs, $5 \mu \mathrm{m}$ particle diameter mixed-E PL gel columns connected in line to the GPC system. Samples were detected using a refractive index detector. The system was calibrated using poly(ethylene glycol) or polystyrene standards (PolymerLabs) in the range of molecular weights 43580-106 g.mol-1. The set dn/dc value (0.050) was calculated as a weighed average of the reported $\mathrm{dn} / \mathrm{dc}$ values for PEG $(0.068)$ and PLA (0.042). ${ }^{32}$

Synthesis of poly((D,L)lactide-co-glycolide)-block-poly(ethylene glycol)-blockpoly ((D,L)lactide-co-glycolide)

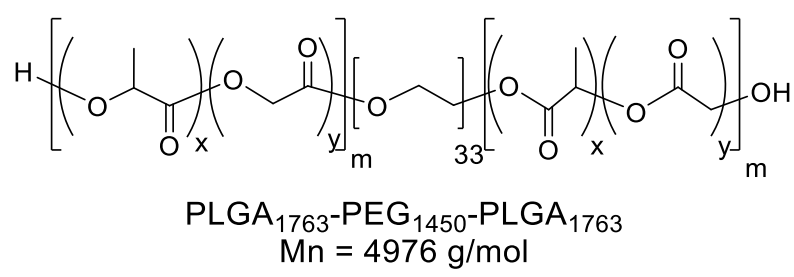

In a flame-dried Schlenk, poly(ethylene glycol $)_{33}(5.0 \mathrm{~g}, 3.44 \mathrm{mmol}, 1$ equiv. $)$ was heated under vacuum at $100{ }^{\circ} \mathrm{C}$ for $2 \mathrm{~h}$. (D,L)-lactide ( $8.6 \mathrm{~g}, 59.6 \mathrm{mmol}, 17$ equiv.) and glycolide (1.6 g, 13.8 mmol, 4 equiv.) were added to the melt under a nitrogen flux. The mixture was heated at $140{ }^{\circ} \mathrm{C}$ until complete melting. The mixture was dried under vacuum at $140{ }^{\circ} \mathrm{C}$ for $30 \mathrm{~min}$ and Tin(II) 2-ethylhexanoate (20 mg, $0.04 \mathrm{mmol}, 0.01$ equiv.) was added. The Schlenk was purged with nitrogen and the mixture was stirred at $140{ }^{\circ} \mathrm{C}$ for $15 \mathrm{~h}$. The reaction was cooled down to room 
temperature and the solid was dissolved in acetone. The organic phase was added dropwise to $100 \mathrm{~mL}$ of cold water. The mixture was stirred at $4{ }^{\circ} \mathrm{C}$ until complete dissolution. The aqueous phase was heated to $80{ }^{\circ} \mathrm{C}$ and the precipitate was isolated by decantation and dissolved again in acetone. This process was repeated twice, and the precipitate was dissolved in dichloromethane, dried over magnesium sulfate, filtered and the solvent was removed under vacuum. The residue was dried under vacuum at $40{ }^{\circ} \mathrm{C}$ for $48 \mathrm{~h}$ to yield the desired product as a transparent gum $(10.78 \mathrm{~g}, 2.17 \mathrm{mmol}, 63 \%)$.

${ }^{1}$ H NMR (400 MHz, CDCl $) \delta 5.28$ - 4.98 (m, 42H), 4.93 - 4.48 (m, 18H), 4.42 - 4.16 (m, 6H), $3.62(\mathrm{~s}, 132 \mathrm{H}), 1.62-1.41(\mathrm{~m}, 125 \mathrm{H})$.

${ }^{13}$ C NMR (101 MHz, CDCl3) $\delta$ 169.5, 166.5, 70.7, 69.3, 69.1, 16.8.

\section{Synthesis of MM176B}

\section{2-(thiophen-2-yl)-1,3-dioxane (1)}<smiles>O=Cc1cccs1</smiles>
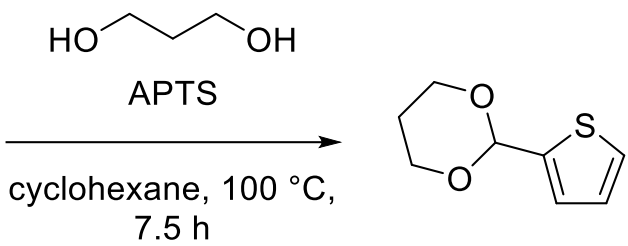

A mixture of 2-thiophenecarbaldehyde $(1.5 \mathrm{~mL}, 16 \mathrm{mmol})$, PTSA monohydrate $(610 \mathrm{mg}, 3.2$ mmol), 1,3-propandiol ( $2.3 \mathrm{~mL}, 32 \mathrm{mmol})$ in cyclohexane $(32 \mathrm{~mL})$ was refluxed in a DeanStark for $7.5 \mathrm{~h}$. The mixture was cooled, filtered and the organic layer was washed with a saturated solution of $\mathrm{NaHCO}_{3}(2 \times 30 \mathrm{~mL})$, dried over $\mathrm{MgSO}_{4}$, filtered and evaporated under reduced pressure to give the desired compound $1(2.3 \mathrm{~g}, 84 \%)$ as a brown oil that was used without purification.

${ }^{1}$ H NMR (400 MHz, CDCl3) $\delta 7.29(\mathrm{dd}, J=5.0,1.2 \mathrm{~Hz}, 1 \mathrm{H}), 7.14-7.11(\mathrm{~m}, 1 \mathrm{H}), 6.99$ (dd, $J$ $=5.0,3.6 \mathrm{~Hz}, 1 \mathrm{H}), 5.75(\mathrm{~s}, 1 \mathrm{H}), 4.33-4.19(\mathrm{~m}, 2 \mathrm{H}), 4.04-3.91(\mathrm{~m}, 2 \mathrm{H}), 2.29-2.17(\mathrm{~m}, 1 \mathrm{H})$, $1.47-1.42(\mathrm{~m}, 1 \mathrm{H})$.

${ }^{13}$ C NMR (101 MHz, CDCl $) \delta 141.7,126.6,125.8,125.1,98.5,67.5,25.6$.

$\mathbf{L C} / \mathbf{M S}(\mathbf{E S I})^{+} \mathrm{m} / z:[\mathrm{M}+\mathrm{H}]^{+}=171.1$ (retention time $2.51 \mathrm{~min}$ ).

\section{1-(5-(1,3-dioxan-2-yl)thiophen-2-yl)ethan-1-ol (2)}



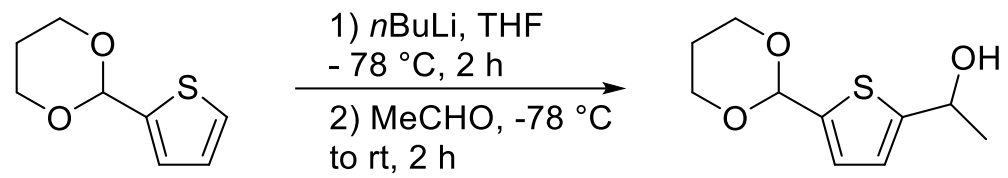

A solution of $n$-BuLi (1.95 M in cyclohexane, $2.9 \mathrm{~mL}$ ) was added dropwise at $-78{ }^{\circ} \mathrm{C}$ to a solution of 1 ( $817 \mathrm{mg}, 4.80 \mathrm{mmol})$ in dry THF $(16 \mathrm{~mL})$. The resulting mixture was stirred at the same temperature for $2 \mathrm{~h}$ and acetaldehyde $(0.805 \mathrm{~mL}, 14.1 \mathrm{mmol})$ was added dropwise. The reaction mixture was warmed at room temperature and stirred for $2 \mathrm{~h}$. The reaction mixture was cooled at $0{ }^{\circ} \mathrm{C}$ and quenched with a saturated solution of $\mathrm{NaHCO}_{3}(30 \mathrm{~mL})$ and the aqueous layer was extracted with EtOAc $(3 \times 60 \mathrm{~mL})$. The combined organic layers were dried over $\mathrm{MgSO}_{4}$, filtered and evaporated under reduced pressure. The crude product was purified by silica gel chromatography (cyclohexane to EtOAc/cyclohexane 4:6) to give the desired compound 2 (896 $\mathrm{mg}, 87 \%)$ as a yellow oil.

${ }^{1}$ H NMR (400 MHz, CDCl3) $\delta 6.96(\mathrm{dd}, J=3.6,0.6 \mathrm{~Hz}, 1 \mathrm{H}), 6.84(\mathrm{dd}, J=3.6,0.7 \mathrm{~Hz}, 1 \mathrm{H})$, $5.69(\mathrm{~s}, 1 \mathrm{H}), 5.06(\mathrm{q}, J=6.4 \mathrm{~Hz}, 1 \mathrm{H}), 4.26-4.22(\mathrm{~m}, 2 \mathrm{H}), 4.00-3.93(\mathrm{~m}, 2 \mathrm{H}), 2.30-2.14(\mathrm{~m}$, $1 \mathrm{H}), 1.56(\mathrm{~d}, J=6.4 \mathrm{~Hz}, 3 \mathrm{H}), 1.46-1.41(\mathrm{~m}, 1 \mathrm{H})$.

LC/MS (ESI) ${ }^{+} m / z:[\mathrm{M}+\mathrm{H}]^{+}=215.2$ (retention time $2.25 \mathrm{~min}$ ).

\section{1-(5-(1,3-dioxan-2-yl)thiophen-2-yl)ethan-1-one (3)}<smiles>CC(O)c1ccc(C2OCCCO2)s1</smiles>
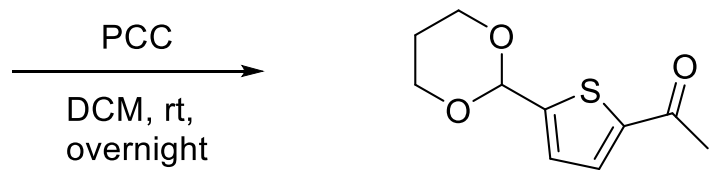

To a solution of alcohol 2 (260 mg, $1.21 \mathrm{mmol})$ in DCM (7 mL) was added in one portion PCC (415 mg, $2.06 \mathrm{mmol}$ ). The resulting mixture was stirred overnight at room temperature. The reaction was filtered on a pad of silica and washed with DCM. The solvent was removed under reduced pressure and the crude mixture was purified by silica gel chromatography (cyclohexane to EtOAc/cyclohexane 4:6) to give the desired compound 3 (166 mg, 65\%) as a white solid.

${ }^{1} \mathbf{H}$ NMR (400 MHz, CDCl $) \delta 7.60(\mathrm{~d}, J=3.9 \mathrm{~Hz}, 1 \mathrm{H}), 7.14(\mathrm{dd}, J=3.9,0.7 \mathrm{~Hz}, 1 \mathrm{H}), 5.73$ (s, $1 \mathrm{H}), 4.35-4.20(\mathrm{~m}, 2 \mathrm{H}), 4.07-3.92(\mathrm{~m}, 2 \mathrm{H}), 2.55(\mathrm{~s}, 3 \mathrm{H}), 2.29$ - $2.19(\mathrm{~m} \mathrm{1H}), 1.51-1.45(\mathrm{~m}$, $1 \mathrm{H})$.

${ }^{13}$ C NMR (101 MHz, CDCl3) $\delta$ 190.9, 149.9, 144.1, 132.0, 125.7, 97.9, 67.5, 26.9, 25.6.

LC/MS (ESI) ${ }^{+} m / z:[\mathrm{M}+\mathrm{H}]^{+}=213.1,[2 \mathrm{M}+\mathrm{H}]^{+}=425.3$ (retention time $2.44 \mathrm{~min}$ ). 


\section{1-(5-(1,3-dioxan-2-yl)thiophen-2-yl)-2-bromoethan-1-one (4)}<smiles>CC(=O)c1ccc(C2OCCCO2)s1</smiles>

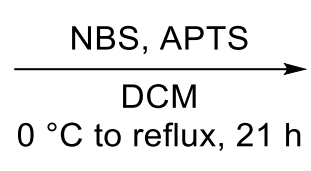<smiles>O=C(CBr)c1ccc(C2OCCCO2)s1</smiles>

A solution of ketone $3(160 \mathrm{mg}, 0.75 \mathrm{mmol})$ in DCM $(0.5 \mathrm{~mL})$ was added at $0{ }^{\circ} \mathrm{C}$ to a solution of NBS (160 mg, $0.90 \mathrm{mmol})$, PTSA monohydrate (14 mg, $0.075 \mathrm{mmol})$ in DCM (1 mL). The resulting mixture was refluxed for $4 \mathrm{~h}$. Water $(5 \mathrm{~mL})$ was added and the aqueous layer was extracted with DCM (2 x $5 \mathrm{~mL})$. The combined organic layers were washed with a saturated solution of $\mathrm{NaHCO}_{3}(10 \mathrm{~mL})$, dried over $\mathrm{MgSO}_{4}$, filtered and evaporated under reduced pressure. The crude was purified by silica gel chromatography (cyclohexane to EtOAc/cyclohexane 4:6) to give the desired compound 4 (120 mg, 55\%) as a white solid.

${ }^{1}$ H NMR (400 MHz, CDCl$) \delta 7.71(\mathrm{~d}, J=3.9 \mathrm{~Hz}, 1 \mathrm{H}), 7.18(\mathrm{dd}, J=3.9,0.7 \mathrm{~Hz}, 1 \mathrm{H}), 5.74(\mathrm{~s}$, 1H), 4.35 (s, 2H), $4.33-4.20(\mathrm{~m}, 2 \mathrm{H}), 4.05-3.95(\mathrm{~m}, 2 \mathrm{H}), 2.34-2.16(\mathrm{~m}, 1 \mathrm{H}), 1.53-1.43$ $(\mathrm{m}, 1 \mathrm{H})$.

${ }^{13}$ C NMR (101 MHz, CDCl $) \delta 184.6,151.6,140.2,133.3,125.9,97.7,67.5,30.7,25.5$.

LC/MS (ESI) ${ }^{+} \mathrm{m} / z:[\mathrm{M}+\mathrm{H}]^{+}=291.1,293.0,3$ (retention time $2.79 \mathrm{~min}$ ).

Ethyl 4-(5-formylthiophen-2-yl)thiazole-2-carboxylate (5)<smiles>O=C(CBr)c1ccc(C2OCCCO2)s1</smiles><smiles>CCOC(=O)C(N)=S</smiles>

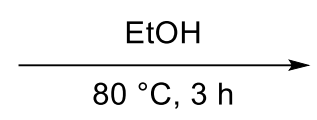<smiles>CCOC(=O)c1nc(-c2ccc(C=O)s2)cs1</smiles>

In a sealed tube, a mixture of $4(100 \mathrm{mg}, 0.34 \mathrm{mmol})$, ethylthioxamate $(65 \mathrm{mg}, 0.49 \mathrm{mmol})$ in $\mathrm{EtOH}(2 \mathrm{~mL})$ was heated at $80{ }^{\circ} \mathrm{C}$ for $3 \mathrm{~h}$. The precipitate was filtered off and the solvent was removed under reduced pressure. The crude product was engaged in the next step without purification.

LC/MS (ESI) ${ }^{+} m / z:[\mathrm{M}+\mathrm{H}]^{+}=268.1 ;[2 \mathrm{M}+\mathrm{H}]^{+}=535.4$ (retention time $3.01 \mathrm{~min}$ ).

\section{5-fluoro-2-(methylamino)-N-phenylbenzamide (6)}<smiles>Cn1c(=O)oc(=O)c2cc(F)ccc21</smiles><smiles>Nc1ccccc1</smiles><smiles>CNc1ccc(F)cc1C(=O)Nc1ccccc1</smiles> 
In a sealed tube, a mixture of 5-fluoro- $\mathrm{N}$-methyl isatoic anhydride (500 mg, $2.56 \mathrm{mmol})$, aniline $(230 \mu \mathrm{L}, 2.56 \mathrm{mmol})$ in DMF was heated at $130{ }^{\circ} \mathrm{C}$ for $18 \mathrm{~h}$. EtOAc $(5 \mathrm{~mL})$ was added and the organic layer was washed with water $(5 \mathrm{~mL})$. The aqueous layer was extracted with EtOAc (2 x $10 \mathrm{~mL}$ ) and the combined organic layer were dried over $\mathrm{MgSO}_{4}$, filtered and evaporated under reduced pressure. The crude product was purified by silica gel chromatography (cyclohexane to EtOAc/cyclohexane 3:7) to give the desired compound 6 (499 $\mathrm{mg}, 80 \%$ ) as a white solid.

${ }^{1} \mathbf{H}$ NMR (400 MHz, CDCl 3$) \delta 7.71(\mathrm{~s}, 1 \mathrm{H}), 7.58-7.51(\mathrm{~m}, 2 \mathrm{H}), 7.41-7.33(\mathrm{~m}, 2 \mathrm{H}), 7.23$ (dd, $J=9.2,2.9 \mathrm{~Hz}, 1 \mathrm{H}), 7.20-7.09(\mathrm{~m}, 2 \mathrm{H}), 6.69$ (dd, $J=9.1,4.5 \mathrm{~Hz}, 1 \mathrm{H}), 2.86(\mathrm{~s}, 3 \mathrm{H})$.

LC/MS (ESI) ${ }^{+} m / z:[\mathrm{M}+\mathrm{H}]^{+}=245.3$ (retention time $\left.3.18 \mathrm{~min}\right)$.

Ethyl 4-(5-(6-fluoro-1-methyl-4-oxo-3-phenyl-1,2,3,4-tetrahydroquinazolin-2yl)thiophen-2-yl)thiazole-2-carboxylate (7)<smiles>CCOc1nc(-c2ccc(C=O)s2)cs1</smiles><smiles>CCOc1nc(-c2ccc(C3N(C)c4ccc(F)cc4C(=O)N3c3ccccc3)s2)cs1</smiles>

To a solution of $\mathbf{6}(142 \mathrm{mg}, 0.58 \mathrm{mmol})$ in THF $(10 \mathrm{~mL})$ were added aldehyde $5(0.53 \mathrm{mmol})$ and PTSA.H2O. The reaction was stirred at $90^{\circ} \mathrm{C}$ for $18 \mathrm{~h}$. EtOAc $(10 \mathrm{~mL})$ was added and the organic layer was washed with a saturated solution of $\mathrm{NaHCO} 3$ and then the aqueous layer was extracted with EtOAc ( 2 x $15 \mathrm{~mL})$. The combined organic layer were dried over $\mathrm{MgSO}_{4}$, filtered and evaporated under reduced pressure. The crude product was purified by silica gel chromatography (cyclohexane to EtOAc/cyclohexane 35:65) to give the desired compound 7 (68 mg, 26\% over two steps) as a yellow solid.

${ }^{1}$ H NMR (400 MHz, CDCl 3$) \delta 7.79(\mathrm{dd}, J=8.7,3.1 \mathrm{~Hz}, 1 \mathrm{H}), 7.51(\mathrm{~s}, 1 \mathrm{H}), 7.42-7.27$ (m, $6 \mathrm{H}), 7.21-7.10(\mathrm{~m}, 1 \mathrm{H}), 6.85(\mathrm{dd}, J=3.7,0.5 \mathrm{~Hz}, 1 \mathrm{H}), 6.66(\mathrm{dd}, J=8.9,4.1 \mathrm{~Hz}, 1 \mathrm{H}), 5.98(\mathrm{~s}$, $1 \mathrm{H}), 4.48(\mathrm{q}, J=7.1 \mathrm{~Hz}, 2 \mathrm{H}), 3.00(\mathrm{~s}, 3 \mathrm{H}), 1.44(\mathrm{t}, J=7.1 \mathrm{~Hz}, 3 \mathrm{H})$.

LC/MS (ESI) ${ }^{+} m / z:[\mathrm{M}+\mathrm{H}]^{+}=494.3 ;[2 \mathrm{M}+\mathrm{H}]^{+}=987.7$ (retention time $3.35 \mathrm{~min}$ ).

\section{6-fluoro-2-(5-(2-(hydroxymethyl)thiazol-4-yl)thiophen-2-yl)-1-methyl-3-phenyl-2,3-} dihydroquinazolin-4(1H)-one (8, MM176B) 

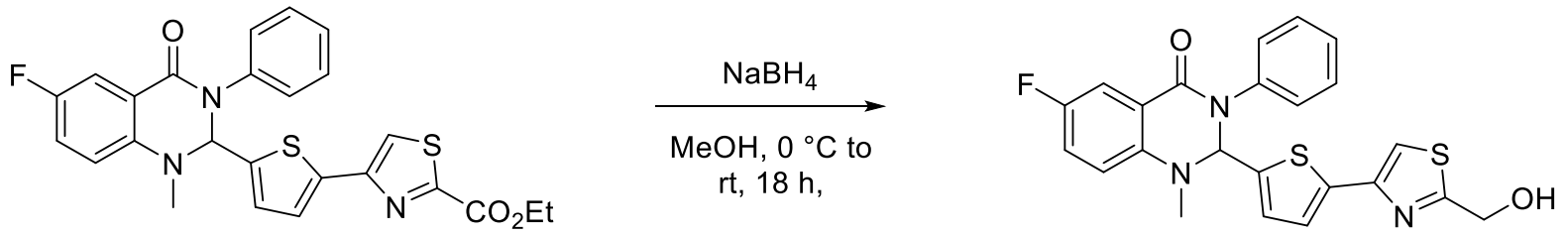

To a solution of $7(68 \mathrm{mg}, 0.14 \mathrm{mmol})$ in $\mathrm{MeOH}(6.6 \mathrm{~mL})$ was added at $0{ }^{\circ} \mathrm{C}$ sodium borohydride (75 mg, $2.0 \mathrm{mmol})$. The resulting mixture was stirred at room temperature for 18 h. Brine $(30 \mathrm{~mL})$ was added and a $5 \% \mathrm{HCl}$ solution was added until $\mathrm{pH}=7$. The aqueous layer was extracted with EtOAc ( 3 x $50 \mathrm{~mL}$ ). The combined organic layer were dried over $\mathrm{MgSO}_{4}$, filtered and evaporated under reduced pressure to give the desired compound $\mathbf{8}(70 \mathrm{mg})$ as a yellow solid.

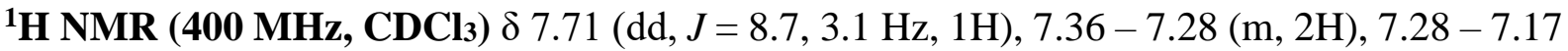
(m, 4H), $7.13-7.05(\mathrm{~m}, 2 \mathrm{H}), 6.75(\mathrm{~d}, J=3.7 \mathrm{~Hz}, 1 \mathrm{H}), 6.59$ (dd, $J=8.9,4.1 \mathrm{~Hz}, 1 \mathrm{H}), 5.90(\mathrm{~s}$, $1 \mathrm{H}), 4.84(\mathrm{~s}, 2 \mathrm{H}), 2.90(\mathrm{~s}, 3 \mathrm{H})$.

$\mathbf{L C} / \mathbf{M S}(\mathbf{E S I})^{+} m / z:[\mathrm{M}+\mathrm{H}]+=452.3[2 \mathrm{M}+\mathrm{H}]=903.5$ (retention time $3.15 \mathrm{~min}$ )

\section{Preliminary vehicle screening}

Preliminary screenings using classical drug vehicle (Tween 80 5\%, Cremophor EL 5\%, Solutol HS15 5\%, Lutrol F68 5\%, hydroxypropyl- $\beta$-cyclodextrin 10\%, Crysmeb 10\% or Intralipid 20\%) were carried out by the CRO Drugabilis (Villejust, France).

\section{Formulation of Retro-2.1 in PEG-PLA (representative procedure)}

In a round bottom flask, Retro-2.1 (92 mg, $211 \mu \mathrm{mol})$ and PEG-PLA (528 mg, $132 \mu \mathrm{mol})$ were dissolved in acetone $(20 \mathrm{~mL})$. The solvent was removed under reduced pressure to yield a transparent pale-yellow polymeric film which was rehydrated with saline $(15 \mathrm{~mL})$ at $40{ }^{\circ} \mathrm{C}$. a $2 \mathrm{M} \mathrm{NaOH}$ solution in water was added to reach $\mathrm{pH}=7$. The volume was adjusted to $20 \mathrm{~mL}$ with saline and the solution was sterile filtered on a $0.2 \mu \mathrm{m}$ membrane (Millex ${ }^{\circledR}$ ) in $6 \mathrm{~mL}$ sterile vials and stored at $-20{ }^{\circ} \mathrm{C}$ until further use. Retro- 2.1 concentration was determined by HPLC after dilution of the solution in $\mathrm{MeOH}$.

\section{Formulation of Retro-2.1 in PLGA-PEG-PLGA (representative procedure)}

In a round bottom flask, Retro-2.1 $(59.8 \mathrm{mg}, 137 \mu \mathrm{mol})$ and PLGA-PEG-PLGA (3.00 g, 545 $\mu \mathrm{mol})$ were dissolved in acetone $(15 \mathrm{~mL})$. The solvent was removed under reduced pressure to 
yield a translucent pale-yellow polymeric film which was further dried under vacuum for $4 \mathrm{~h}$. The film was rehydrated with saline $(15 \mathrm{~mL})$ at room temperature and a $2 \mathrm{M} \mathrm{NaOH}$ solution in water was added to reach $\mathrm{pH} 7$. The solution was sterile filtered on a $0.2 \mu \mathrm{m}$ membrane (Millex ${ }^{\circledR}$ ) in $6 \mathrm{~mL}$ sterile vials and stored at $4{ }^{\circ} \mathrm{C}$ until further use. Retro- 2.1 concentration was determined by HPLC after dilution of the solution in MeCN.

\section{Retro-2.1 release kinetic from PEG-PLA micelles}

$600 \mu \mathrm{L}$ of a Retro-2.1 in PEG-PLA solution (PEG-PLA $22.4 \mathrm{mg} / \mathrm{mL}$, Retro-2.1 $4.31 \mathrm{mg} / \mathrm{mL}$ ) was placed in a dialysis cassette (MWCO $=3,500 \mathrm{Da}$, Slide-A-Lyzer ${ }^{\mathrm{TM}}$, ThermoFisher). The cassette was immersed in PBS $(2.0 \mathrm{~L})$ under gentle stirring at $25^{\circ} \mathrm{C}$. At each time point, $20 \mu \mathrm{L}$ of the solution inside the cassette was collected, diluted in $\mathrm{MeOH}$ and Retro-2.1 concentration was determined by HPLC-UV (Method 1A). The dialysis buffer was exchanged with fresh PBS every $24 \mathrm{~h}$.

\section{Formulations stability evaluation}

A sample of the formulation was placed in a $500 \mu \mathrm{L}$ Eppendorf and stored at $-20{ }^{\circ} \mathrm{C}, 4{ }^{\circ} \mathrm{C}$, or room temperature $\left(20-25^{\circ} \mathrm{C}\right)$. At each time point, the sample was centrifuged $(15,000 \mathrm{~g}, 5 \mathrm{~min}$, $4{ }^{\circ} \mathrm{C}$ ) and Retro- 2.1 concentration in the supernatant was determined by HPLC.

\section{Animals}

All experiments were performed in accordance with European regulations on care and use of laboratory animals (approval number: D 91272 106). 20 - 23 g female BALB/c mice were provided by Janvier Labs and acclimatized at least for one week before experiments. When indicated, mice were anesthetized with a ketamine (Imalgen ${ }^{\circledR}, 150 \mathrm{mg} / \mathrm{kg}$ ) / xylazine (Rompun ${ }^{\circledR}, 10 \mathrm{mg} / \mathrm{kg}$ ) mixture. All equipment in contact with blood was coated with heparin (Héparine Choay; 5,000 UI/mL).

\section{Formulation administration and blood sampling}

Mice were randomly divided into 8 groups ( $n=3$ mice/group for IV injections, $n=5$ mice/group for IP, and SC administrations). Each group was assigned to a time point (5 min, $15 \mathrm{~min}, 30$ min, 1 h, 2 h, 4 h, 7 h, 24 h or $5 \mathrm{~min}, 30 \mathrm{~min}, 1$ h, 2 h, 4 h, 7 h, 24 h, 48 h for the Retro2.1@PLGA-PEG-PLGA formulation). Mice were weighed and administered with the test 
formulation at $\mathrm{t} 0$. At each time point, mice were anesthetized with a ketamine/xylazine mixture, blood was drawn by cardiac puncture with sodium heparin-coated needle and syringe and the animals were euthanized. Blood was transferred into a sodium heparin-coated Eppendorf which was centrifuged at $16,000 \mathrm{~g}$ for $10 \mathrm{~min}$. Plasma samples were transferred to individual Eppendorf and stored at $-20{ }^{\circ} \mathrm{C}$ until titration.

\section{Retro-2.1 plasmatic concentration determination}

To a mixture of $50 \mu \mathrm{L}$ of mouse plasma and distilled water $(5 \mu \mathrm{L})$ were added $5 \mu \mathrm{L}$ of an internal standard $10 \mu \mathrm{g} / \mathrm{mL}$ solution in water and $300 \mu \mathrm{L}$ of MeCN. The mixture was agitated at $1,500 \mathrm{rpm}$ at room temperature for $10 \mathrm{~min}$. The mixture was then centrifuged at $20,000 \mathrm{~g}$ at $5{ }^{\circ} \mathrm{C}$ for $10 \mathrm{~min}$. The supernatant was isolated and evaporated under a nitrogen flux at $40{ }^{\circ} \mathrm{C}$. The residue was dissolved in $50 \mu \mathrm{L}$ of $\mathrm{MeCN}$. The mixture was centrifuged at $20,000 \mathrm{~g}$ at $5{ }^{\circ} \mathrm{C}$ for $5 \mathrm{~min}$ and the supernatant was analyzed by LC-MS/MS. Retro-2.1 concentration was determined by comparing the intensity of the molecular ion to a calibration curve acquired in the same experimental conditions. The quantitation method was validated in accordance with EMA Guideline on bioanalytical method validation.

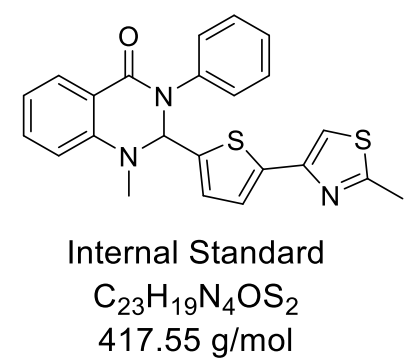

\section{Microsomal stability assay}

Retro-2.1 was incubated at a concentration of $5 \mu \mathrm{M}$ in mouse $(0.5 \mathrm{mg} / \mathrm{mL}$ in PBS, MIC255, batch MIC255030, Biopredic) or human (1.0 mg/mL in PBS, MIC259, batch MIC259822, Biopredic) microsomes at $37{ }^{\circ} \mathrm{C}$ with or without NADPH as a cofactor. At each time point, the enzymatic digestion was stopped by addition of $\mathrm{MeCN}$. The mixture was centrifuged at 20,000 $\mathrm{g}$ for $20 \mathrm{~min}$ and the supernatant was analyzed by LC-MS/MS. 


\section{Cell culture}

HeLa cells (human cervical tumor cells) were maintained in Dulbecco's Modified Eagle's Medium (DMEM, Invitrogen) supplemented with $1 \%$ non-essential amino acid solution (MEM NEAA, Invitrogen), $10 \%$ fetal bovine serum, $100 \mathrm{U} / \mathrm{mL}$ penicillin and $100 \mu \mathrm{g} / \mathrm{mL}$ streptomycin (noted DMEM complete Medium thereafter) at $37{ }^{\circ} \mathrm{C}$ under $5 \% \mathrm{CO}_{2}$. Cells were passed once a week and discarded after the $35^{\text {th }}$ passage.

\section{Shiga toxin cell intoxication assay}

HeLa cells suspended in DMEM complete medium were seeded at a density of 20,000 cells/100 $\mu \mathrm{L} /$ well in a 96-well plate with scintillant-incorporated base (CytoStar-T 96-well plate, PerkinElmer). The plate was incubated at $37{ }^{\circ} \mathrm{C}$ under $5 \% \mathrm{CO}_{2}$ for $24 \mathrm{~h}$. Cells were incubated with increasing concentrations of the test compound by adding $50 \mu \mathrm{L} /$ well compound dilutions in DMEM complete medium at $37{ }^{\circ} \mathrm{C}$ under $5 \% \mathrm{CO}_{2}$ for $4 \mathrm{~h}$. Cells were then challenged with increasing concentration of Stx-1 (from $10^{-9}$ to $10^{-16} \mathrm{M}$ ) in the continuous presence of the test compound at $37{ }^{\circ} \mathrm{C}$ under $5 \% \mathrm{CO}_{2}$ for $15 \mathrm{~h}$. The medium was replaced with $100 \mu \mathrm{L} /$ well DMEM complete medium without leucine and supplemented with $0.5 \mu \mathrm{Ci} / \mathrm{mL}\left[{ }^{14} \mathrm{C}\right]$-leucine and cells were incubated at $37{ }^{\circ} \mathrm{C}$ under $5 \% \mathrm{CO}_{2}$ for $6 \mathrm{~h}$. The plate was read using a Wallac 1450 MicroBeta liquid scintillation counter (PerkinElmer). Number of counts per minute from duplicate wells was plotted against Stx-1 concentration and data were normalized by setting the number of counts per minute of the well containing $10^{-16} \mathrm{M} \mathrm{Stx}-1$ to $100 \%$ protein biosynthesis.

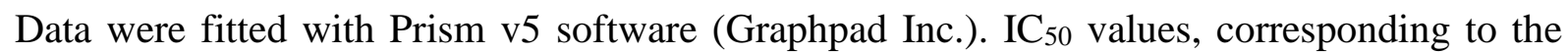
Shiga toxin concentration required to inhibit $50 \%$ of the protein biosynthesis were determined by non-linear regression (equation: $\mathrm{EC}_{50}$ shift). $\mathrm{R}$ was defined as the ratio between the $\mathrm{IC}_{50}$ of the test compound at a given concentration and $\mathrm{IC}_{50}$ of the vehicle. \%protection represents the protection obtained at a given concentration of the test compound compared to the maximum protection achieved in the assay and is calculated with the following formula:

$$
\% \text { protection }=\frac{R-1}{R \max -1} \times 100, \text { with } R=\frac{I C_{50}(\text { test compound })}{I C_{50}(\text { vehicule })}
$$


Test compound concentration was plotted against the \%protection and $\mathrm{EC}_{50}$ value corresponding to the test compound concentration required to achieve $50 \%$ of the maximum protection was determined by non-linear regression (equation: $\log$ (inhibitor) vs. response Variable slope).

\section{Acknowledgements}

The authors thank Eric Doris and Edmond Gravel (Université Paris-Saclay, CEA, INRAE, Département Médicaments et Technologies pour la Santé (DMTS), SCBM, 91191 Gif-surYvette, France) for useful discussion as well as Géraldine Carrot (Université Paris-Saclay, CEA IRAMIS, LICSEN) for the access to a GPC system. This work has been funded by the French National Agency for Research (ANR) under Contracts Anti-HUS ANR-14-CE16-0004 and SMERSEC ANR-20-CE18-0016-01, the Swedish Research Council (K2015-99X-22877-01-6) and the Joint ministerial program of R\&D against CBRNe risks. The Cintrat, Gillet and Pruvost teams are members of LabEx LERMIT (ANR-10-LABX-33). R.V. was funded by the CEA Irtelis international $\mathrm{PhD}$ program.

\section{Supporting Information}

Calibration curve for the titration of Retro-2.1 by HPLC (Fig. S1). Size distribution of PEGPLA micelles encapsulating Retro-2.1 or not (Fig. S2). Stability of the formulation of Retro2.1 in PEG-PLA micelles (Fig. S3). Metabolic stability of Retro-2.1 incubated on human microsomes (Fig. S4). ${ }^{1} \mathrm{H}$ and ${ }^{13} \mathrm{C}$ NMR spectrum and GPC chromatogram of the synthesized PLGA-PEG-PLGA polymer (Fig. S5-S7). Size distribution of PLGA-PEG-PLGA micelles encapsulating Retro-2.1 or not (Fig. S8). Stability of the formulation of Retro-2.1 in PLGAPEG-PLGA micelles (Fig. S9). MM176B synthesis scheme (Fig. S10). 


\section{REFERENCES}

(1) Stechmann, B.; Bai, S.-K.; Gobbo, E.; Lopez, R.; Merer, G.; Pinchard, S.; Panigai, L.; Tenza, D.; Raposo, G.; Beaumelle, B.; Sauvaire, D.; Gillet, D.; Johannes, L.; Barbier, J. Inhibition of Retrograde Transport Protects Mice from Lethal Ricin Challenge. Cell 2010, 141 (2), 231-242. https://doi.org/10.1016/j.cell.2010.01.043.

(2) Noel, R.; Gupta, N.; Pons, V.; Goudet, A.; Garcia-Castillo, M. D.; Michau, A.; Martinez, J.; Buisson, D.-A.; Johannes, L.; Gillet, D.; Barbier, J.; Cintrat, J.-C. NMethyldihydroquinazolinone Derivatives of Retro-2 with Enhanced Efficacy against Shiga Toxin. J. Med. Chem. 2013, 56 (8), 3404-3413. https://doi.org/10.1021/jm4002346.

(3) Gupta, N.; Pons, V.; Noël, R.; Buisson, D.-A.; Michau, A.; Johannes, L.; Gillet, D.; Barbier, J.; Cintrat, J.-C. (S)-N-Methyldihydroquinazolinones Are the Active Enantiomers of Retro-2 Derived Compounds against Toxins. ACS Med. Chem. Lett. 2014, 5 (1), 94-97. https://doi.org/10.1021/ml400457j.

(4) Gupta, N.; Noël, R.; Goudet, A.; Hinsinger, K.; Michau, A.; Pons, V.; Abdelkafi, H.; Secher, T.; Shima, A.; Shtanko, O.; Sakurai, Y.; Cojean, S.; Pomel, S.; Liévin-Le Moal, V.; Leignel, V.; Herweg, J.-A.; Fischer, A.; Johannes, L.; Harrison, K.; Beard, P. M.; Clayette, P.; Le Grand, R.; Rayner, J. O.; Rudel, T.; Vacus, J.; Loiseau, P. M.; Davey, R. A.; Oswald, E.; Cintrat, J.-C.; Barbier, J.; Gillet, D. Inhibitors of Retrograde Trafficking Active against Ricin and Shiga Toxins Also Protect Cells from Several Viruses, Leishmania and Chlamydiales. Chem. Biol. Interact. 2017, 267, 96-103. https://doi.org/10.1016/j.cbi.2016.10.005.

(5) Secher, T.; Shima, A.; Hinsinger, K.; Cintrat, J. C.; Johannes, L.; Barbier, J.; Gillet, D.; Oswald, E. Retrograde Trafficking Inhibitor of Shiga Toxins Reduces Morbidity and Mortality of Mice Infected with Enterohemorrhagic Escherichia Coli. Antimicrob. Agents Chemother. 59 (8), 5010-5013. https://doi.org/10.1128/AAC.00455-15.

(6) Nonnenmacher, M. E.; Cintrat, J.-C.; Gillet, D.; Weber, T. Syntaxin 5-Dependent Retrograde Transport to the Trans-Golgi Network Is Required for Adeno-Associated Virus Transduction. J. Virol. 89 (3), 1673-1687. https://doi.org/10.1128/JVI.02520-14.

(7) Nelson, C. D. S.; Carney, D. W.; Derdowski, A.; Lipovsky, A.; Gee, G. V.; O’Hara, B.; Williard, P.; DiMaio, D.; Sello, J. K.; Atwood, W. J. A Retrograde Trafficking Inhibitor of Ricin and Shiga-Like Toxins Inhibits Infection of Cells by Human and Monkey Polyomaviruses. mBio 4 (6), e00729-13. https://doi.org/10.1128/mBio.00729-13.

(8) Carney, D. W.; Nelson, C. D. S.; Ferris, B. D.; Stevens, J. P.; Lipovsky, A.; Kazakov, T.; DiMaio, D.; Atwood, W. J.; Sello, J. K. Structural Optimization of a Retrograde Trafficking Inhibitor That Protects Cells from Infections by Human Polyoma- and Papillomaviruses. Bioorg. Med. Chem. 2014, 22 (17), 4836-4847. https://doi.org/10.1016/j.bmc.2014.06.053.

(9) Shtanko, O.; Sakurai, Y.; Reyes, A. N.; Noël, R.; Cintrat, J.-C.; Gillet, D.; Barbier, J.; Davey, R. A. Retro-2 and Its Dihydroquinazolinone Derivatives Inhibit Filovirus Infection. Antiviral Res. 2018, 149, 154-163. https://doi.org/10.1016/j.antiviral.2017.11.016. 
(10) Harrison, K.; Haga, I. R.; Pechenick Jowers, T.; Jasim, S.; Cintrat, J.-C.; Gillet, D.; Schmitt-John, T.; Digard, P.; Beard, P. M. Vaccinia Virus Uses Retromer-Independent Cellular Retrograde Transport Pathways To Facilitate the Wrapping of Intracellular Mature Virions during Virus Morphogenesis. J. Virol. 90 (22), 10120-10132. https://doi.org/10.1128/JVI.01464-16.

(11) Sivan, G.; Weisberg, A. S.; Americo, J. L.; Moss, B. Retrograde Transport from Early Endosomes to the Trans-Golgi Network Enables Membrane Wrapping and Egress of Vaccinia Virus Virions. J. Virol. 2016, 90 (19), 8891-8905. https://doi.org/10.1128/JVI.01114-16.

(12) Cruz, L.; Streck, N. T.; Ferguson, K.; Desai, T.; Desai, D. H.; Amin, S. G.; Buchkovich, N. J. Potent Inhibition of Human Cytomegalovirus by Modulation of Cellular SNARE Syntaxin 5. J. Virol. 2016, 91 (1), e01637-16. https://doi.org/10.1128/JVI.01637-16.

(13) Dai, W. wen; Wu, Y.; Bi, J. peng; Wang, J. yu; Wang, S.; Kong, W.; Barbier, J.; Cintrat, J.-C.; Gao, F.; Jiang, Z. ran; Gillet, D.; Jiang, W. heng S. and C. lai. Antiviral Effect of Retro-2.1 against Herpes Simplex Virus Type 2 In Vitro. 2018, 28 (6), 849-859. https://doi.org/10.4014/jmb.1712.12052.

(14) Dai, W.; Wu, Y.; Bi, J.; Lu, X.; Hou, A.; Zhou, Y.; Sun, B.; Kong, W.; Barbier, J.; Cintrat, J.-C.; Gao, F.; Gillet, D.; Su, W.; Jiang, C. Antiviral Effects of Retro-2cycl and Retro-2.1 against Enterovirus 71 in Vitro and in Vivo. Antiviral Res. 2017, 144, 311-321. https://doi.org/10.1016/j.antiviral.2017.07.001.

(15) Canton, J.; Kima, P. E. Targeting Host Syntaxin-5 Preferentially Blocks Leishmania Parasitophorous Vacuole Development in Infected Cells and Limits Experimental Leishmania Infections. Am. J. Pathol. 2012, 181 (4), 1348-1355. https://doi.org/10.1016/j.ajpath.2012.06.041.

(16) Herweg, J.-A.; Pons, V.; Becher, D.; Hecker, M.; Krohne, G.; Barbier, J.; Berger, H.; Rudel, T.; Mehlitz, A. Proteomic Analysis of the Simkania-Containing Vacuole: The Central Role of Retrograde Transport. Mol. Microbiol. 2016, 99 (1), 151-171. https://doi.org/10.1111/mmi.13222.

(17) Holwerda, M.; V'kovski, P.; Wider, M.; Thiel, V.; Dijkman, R. Identification of an Antiviral Compound from the Pandemic Response Box That Efficiently Inhibits SARSCoV-2 Infection In Vitro. Microorganisms 2020, 8 (12), 1872. https://doi.org/10.3390/microorganisms8121872.

(18) Forrester, A.; Rathjen, S. J.; Daniela Garcia-Castillo, M.; Bachert, C.; Couhert, A.; Tepshi, L.; Pichard, S.; Martinez, J.; Munier, M.; Sierocki, R.; Renard, H.-F.; Augusto ValadesCruz, C.; Dingli, F.; Loew, D.; Lamaze, C.; Cintrat, J.-C.; Linstedt, A. D.; Gillet, D.; Barbier, J.; Johannes, L. Functional Dissection of the Retrograde Shiga Toxin Trafficking Inhibitor Retro-2. Nat. Chem. Biol. 2020, 16 (3), 327-336. https://doi.org/10.1038/s41589-020-0474-4.

(19) Torchilin, V. P. Structure and Design of Polymeric Surfactant-Based Drug Delivery Systems. J. Controlled Release 2001, 73 (2-3), 137-172. https://doi.org/10.1016/s01683659(01)00299-1. 
(20) Cho, H.; Gao, J.; Kwon, G. S. PEG-b-PLA Micelles and PLGA-b-PEG-b-PLGA Sol-Gels for Drug Delivery. J. Controlled Release 2016, 240, 191-201. https://doi.org/10.1016/j.jconrel.2015.12.015.

(21) Kim, T.-Y.; Kim, D.-W.; Chung, J.-Y.; Shin, S. G.; Kim, S.-C.; Heo, D. S.; Kim, N. K.; Bang, Y.-J. Phase I and Pharmacokinetic Study of Genexol-PM, a Cremophor-Free, Polymeric Micelle-Formulated Paclitaxel, in Patients with Advanced Malignancies. Clin. Cancer Res. 2004, 10 (11), 3708-3716. https://doi.org/10.1158/1078-0432.CCR-03-0655.

(22) Park, I. H.; Sohn, J. H.; Kim, S. B.; Lee, K. S.; Chung, J. S.; Lee, S. H.; Kim, T. Y.; Jung, K. H.; Cho, E. K.; Kim, Y. S.; Song, H. S.; Seo, J. H.; Ryoo, H. M.; Lee, S. A.; Yoon, S. Y.; Kim, C. S.; Kim, Y. T.; Kim, S. Y.; Jin, M. R.; Ro, J. An Open-Label, Randomized, Parallel, Phase III Trial Evaluating the Efficacy and Safety of Polymeric MicelleFormulated Paclitaxel Compared to Conventional Cremophor EL-Based Paclitaxel for Recurrent or Metastatic HER2-Negative Breast Cancer. Cancer Res. Treat. 2017, 49 (3), 569-577. https://doi.org/10.4143/crt.2016.289.

(23) Tyrrell, Z. L.; Shen, Y.; Radosz, M. Fabrication of Micellar Nanoparticles for Drug Delivery through the Self-Assembly of Block Copolymers. Prog. Polym. Sci. 2010, 35 (9), 1128-1143. https://doi.org/10.1016/j.progpolymsci.2010.06.003.

(24) Modi, S.; Anderson, B. D. Determination of Drug Release Kinetics from Nanoparticles: Overcoming Pitfalls of the Dynamic Dialysis Method. Mol. Pharm. 2013, 10 (8), 30763089. https://doi.org/10.1021/mp400154a.

(25) Chen, H.; Kim, S.; He, W.; Wang, H.; Low, P. S.; Park, K.; Cheng, J.-X. Fast Release of Lipophilic Agents from Circulating PEG-PDLLA Micelles Revealed by in Vivo Forster Resonance Energy Transfer Imaging. Langmuir ACS J. Surf. Colloids 2008, 24 (10), 5213-5217. https://doi.org/10.1021/la703570m.

(26) Zhang, Z.; Tang, W. Drug Metabolism in Drug Discovery and Development. Acta Pharm. Sin. B 2018, 8 (5), 721-732. https://doi.org/10.1016/j.apsb.2018.04.003.

(27) Zhang, D.; Luo, G.; Ding, X.; Lu, C. Preclinical Experimental Models of Drug Metabolism and Disposition in Drug Discovery and Development. Acta Pharm. Sin. B 2012, 2 (6), 549-561. https://doi.org/10.1016/j.apsb.2012.10.004.

(28) Ortiz de Montellano, P. R. Hydrocarbon Hydroxylation by Cytochrome P450 Enzymes. Chem. Rev. 2010, 110 (2), 932-948. https://doi.org/10.1021/cr9002193.

(29) Jeong, B.; Choi, Y. K.; Bae, Y. H.; Zentner, G.; Kim, S. W. New Biodegradable Polymers for Injectable Drug Delivery Systems. J. Controlled Release 1999, 62 (1), 109-114. https://doi.org/10.1016/S0168-3659(99)00061-9.

(30) Jeong, B.; Kim, S. W.; Bae, Y. H. Thermosensitive Sol-Gel Reversible Hydrogels. Adv. Drug Deliv. Rev. 2002, 54 (1), 37-51. https://doi.org/10.1016/S0169-409X(01)00242-3.

(31) Steinman, N. Y.; Haim-Zada, M.; Goldstein, I. A.; Goldberg, A. H.; Haber, T.; Berlin, J. M.; Domb, A. J. Effect of PLGA Block Molecular Weight on Gelling Temperature of 
PLGA-PEG-PLGA Thermoresponsive Copolymers. J. Polym. Sci. Part Polym. Chem. 2019, 57 (1), 35-39. https://doi.org/10.1002/pola.29275.

(32) Qian, H.; Wohl, A. R.; Crow, J. T.; Macosko, C. W.; Hoye, T. R. A Strategy for Control of "Random" Copolymerization of Lactide and Glycolide: Application to Synthesis of PEG-b-PLGA Block Polymers Having Narrow Dispersity. Macromolecules 2011, 44 (18), 7132-7140. https://doi.org/10.1021/ma201169z. 